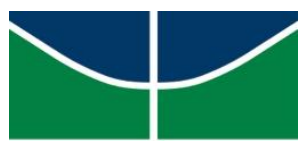

UNIVERSIDADE DE BRASÍLIA

INSTITUTO DE CIÊNCIAS HUMANAS

DEPARTAMENTO DE GEOGRAFIA

PROGRAMA DE PÓS-GRADUAÇÃO EM GEOGRAFIA

\title{
COMPARAÇÃO ENTRE CLASSIFICADORES SUPERVISIONADOS PARA FINS DE ANÁLISE MULTITEMPORAL DO USO E COBERTURA DA TERRA NO ENTORNO DO RESERVATÓRIO DA USINA HIDRELÉTRICA DE CORUMBÁ IV/GO
}

NÁJLA VILAR AIRES DE MOURA

Orientador: Osmar Abílio de Carvalho Júnior

Dissertação de Mestrado

BRASÍLIA/DF, junho de 2016. 


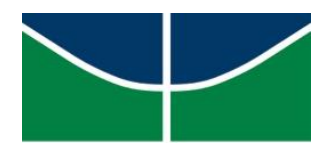

UNIVERSIDADE DE BRASÍLIA

INSTITUTO DE CIÊNCIAS HUMANAS

DEPARTAMENTO DE GEOGRAFIA

PROGRAMA DE PÓS-GRADUAÇÃO EM GEOGRAFIA

\title{
COMPARAÇÃO ENTRE CLASSIFICADORES SUPERVISIONADOS PARA FINS DE ANÁLISE MULTITEMPORAL DO USO E COBERTURA DA TERRA NO ENTORNO DO RESERVATÓRIO DA USINA HIDRELÉTRICA DE CORUMBÁ IV/GO
}

\author{
NÁJLA VILAR AIRES DE MOURA
}

Dissertação de Mestrado submetida ao Departamento de Geografia da Universidade de Brasília, como parte dos requisitos necessários para a obtenção do Grau de Mestra em Geografia, área de concentração Gestão Ambiental e Territorial, na linha de pesquisa Análise de Sistemas Naturais.

Aprovado por:

Prof. Dr. Osmar Abílio de Carvalho Júnior (UnB) (Orientador)

Edson Eyji Sano (EMBRAPA)

(Examinador Externo)

Raul Sanchez Vicens (UFF)

(Examinador Externo)

Éder de Souza Martins (EMBRAPA)

(Examinador Externo - Suplente)

Brasília/DF, junho de 2016. 


\section{FICHA CATALOGRÁFICA}

MOURA, NÁJLA VILAR AIRES DE

Comparação entre classificadores supervisionados para fins de análise multitemporal do uso e cobertura da terra no entorno do reservatório da Usina hidrelétrica de Corumbá IV/GO. 53p. (UnB-IH-GEA, Mestrado, Gestão Ambiental e Territorial, 2016).

Dissertação de Mestrado - Universidade de Brasília. Departamento de Geografia

1. UnB-IH-GEA

2. Sensoriamento Remoto

3. Análise multitemporal

\section{UNIVERSIDADE DE BRASÍLIA}

INSTITUTO DE CIÊNCIAS HUMANAS

DEPARTAMENTO DE GEOGRAFIA

PROGRAMA DE PÓS-GRADUAÇÃO EM GEOGRAFIA

É concedida à Universidade de Brasília permissão para reproduzir cópias desta dissertação e emprestar ou vender tais cópias somente para propósitos acadêmicos e científicos. A autora reserva outros direitos de publicação e nenhuma parte desta dissertação de mestrado pode ser reproduzida sem a autorização por escrito da autora.

Nájla Vilar Aires de Moura 


\section{AGRADECIMENTO}

Aos professores Osmar Abílio de Carvalho Júnior, Renato Fontes Guimarães e Roberto Arnaldo Trancoso Gomes pela orientação na realização da presente pesquisa.

Aos membros da banca Edson Eyji Sano e Raul Sanchez Vicens pelas valorosas contribuições.

Aos queridos amigos Verônica Moreira Ramos e Vítor Luís Curvelo Sarno pelo incentivo e ajuda desde o processo seletivo até o dia da defesa.

Ao Instituto Brasileiro do Meio Ambiente e dos Recursos Naturais Renováveis (Ibama) pela concessão de afastamento para a conclusão desta pesquisa. 


\section{RESUMO}

O aumento do consumo energético no Brasil demanda a construção de novas usinas hidrelétricas, o que implica na necessidade do poder público desenvolver ferramentas efetivas de mapeamento do uso e cobertura da terra, no entorno dos reservatórios para garantir a manutenção das Áreas de Preservação Permanentes (APPs), protegidas por lei. Com esse propósito, o sensoriamento remoto, em especial o uso de classificadores automáticos, é compreendido como uma maneira rápida para obtenção de dados. Neste contexto, o objetivo desta pesquisa é analisar diferentes classificadores automáticos para o mapeamento de uso e cobertura da terra no entorno do reservatório da usina hidrelétrica de Corumbá IV/GO e, posteriormente, fazer a análise multitemporal das mudanças ocorridas na localidade. Os classificadores utilizados foram Máxima Verossimilhança (MaxVer), Distância Mahalanobis, Mínima Distância, Paralelepípedo, Spectral Angle Mapper (SAM), Support Vector Machine (SVM) e Spectral Information Divergence (SID). Para verificar a eficácia dos classificadores, estes foram comparados com a classificação manual, elaborada a partir de imagem Landsat. A classificação multitemporal (anos de 1988, 1998, 2005, 2006, 2008, 2010, 2014 e 2015) do uso e ocupação da terra foi feita para os oito municípios goianos nos quais o reservatório se localiza. Na comparação entre o desempenho dos classificadores o SVM apresentou os melhores resultados para a área de estudo (77,3\% de acurácia global e 0,64 de índice Kappa). O mapeamento, elaborado por este classificador, demonstrou que a vegetação nativa representa apenas $56 \%$ da faixa de terra de 100 metros a partir da margem do reservatório, demonstrando o descumprimento do percentual mínimo de APP.

PALAVRAS-CHAVE: diagnóstico ambiental, classificação automatizada, testes de classificadores. 


\begin{abstract}
The increase in energy consumption in Brazil requires the construction of new hydroelectric plants, which implies the need for the government to develop effective tools for mapping the land use and land cover, around the reservoirs to ensure the maintenance of the Permanent Preservation Areas, protected by law. For this purpose, remote sensing, in particular the use of automatic classifiers, is understood as a quick way to obtain data. In this context, the aim of this study is to analyze different automatic classifiers for mapping the land use and land cover around the reservoir of the hydroelectric plant Corumbá IV, Goias, Brazil, and subsequently make the multitemporal analysis of changes in the locality. The classifiers used were Maximum Likelihood, Mahalanobis Distance, Minimum Distance, Parallelepiped, Spectral Angle Mapper (SAM), Support Vector Machine (SVM) and Spectral Information Divergence (SID). To verify the effectiveness of classifiers, they were compared with manual classification, drawn from Landsat image. The multitemporal classification of the land use and land cover was made for the eight municipalities of Goiás in which the reservoir is located (for 1988, 1998, 2005, 2006, 2008, 2010, 2014 and 2015). Comparing the performance of classifiers, SVM showed the best results for the study area $(77.3 \%$ overall accuracy and 0.64 Kappa index). The map prepared by this classifier showed that the native vegetation covers only $56 \%$ of the strip of land 100 meters from the shore of the reservoir, demonstrating noncompliance with the minimum of Permanent Preservation Area percentage.
\end{abstract}

KEYWORDS: environmental assessment, automated classification, classifiers test. 


\section{SUMÁRIO}

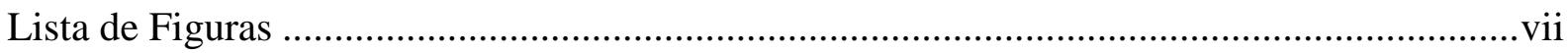

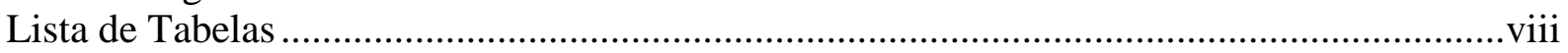

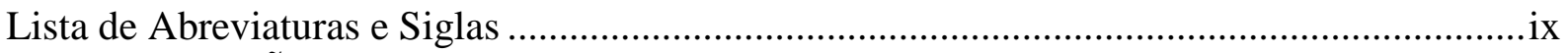

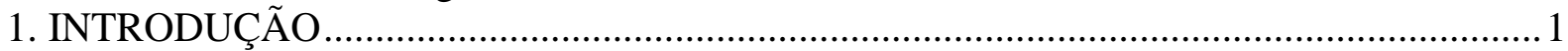

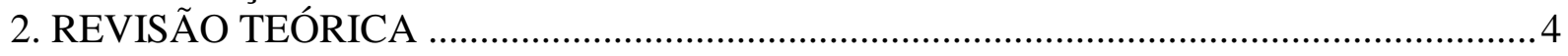

2.1. Classificação Automatizada de Imagens de Satélite ......................................................

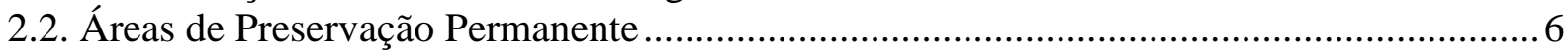

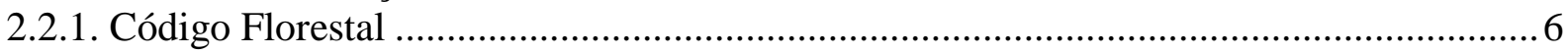

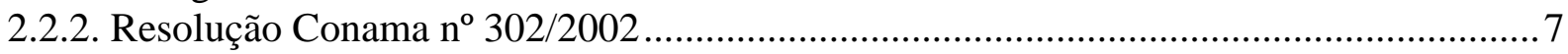

2.2.3. Política Florestal do Estado de Goiás (Lei $\mathrm{n}^{\circ}$ 18.104/2013) ........................................ 8

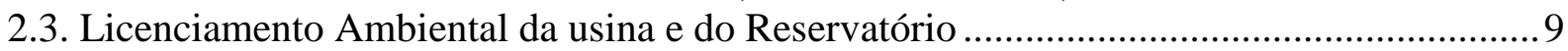

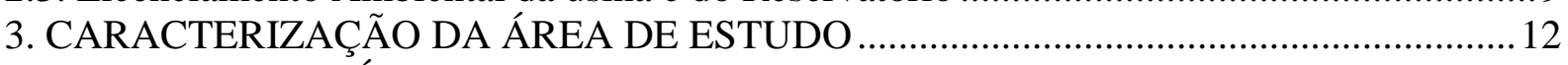

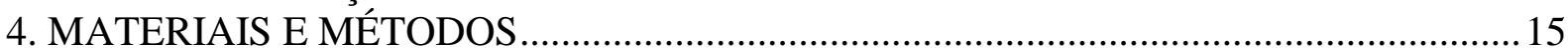

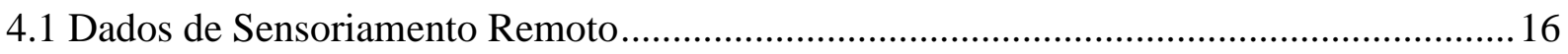

4.2. Análise Comparativa entre os Métodos de Classificação Supervisionada ........................ 18

4.2.1. Aplicação dos Métodos de Classificação Supervisionada para a Área Teste.....................18

4.2.2 Análise de acurácia e definição do melhor método de classificação supervisionada...... 18

4.3. Análise Multitemporal do Uso e Cobertura da Terra nas APPs do Reservatório de

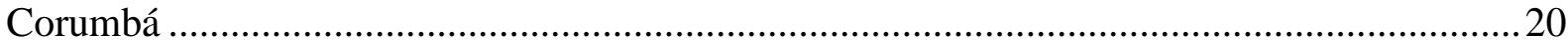

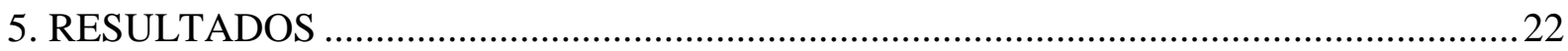

5.1 Resultados da Análise Comparativa entre Métodos de Classificação Supervisionada ...... 22

5.1.1 Resultado da classificação manual da imagem RapidEye (imagem de referência) ........22

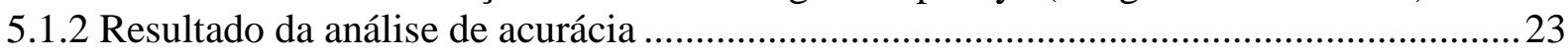

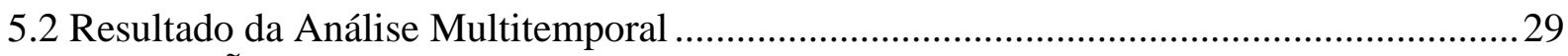

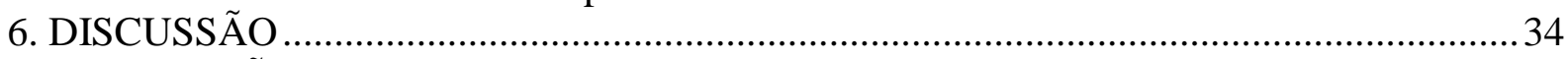

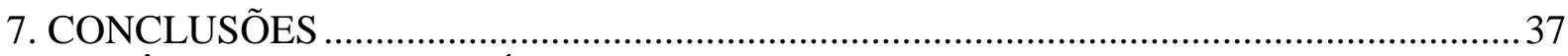

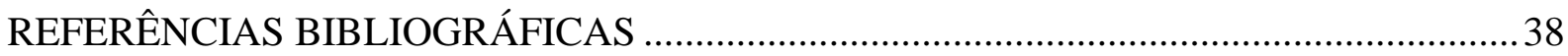




\section{Lista de Figuras}

Figura 1: Mapa de localização da área de estudo. 12

Figura 2: Fluxograma dos procedimentos metodológicos.................................................. 15 Figura 3: Área para o teste dos classificadores (buffer de 1000 metros a partir da margem do reservatório)

Figura 4: APP de 100 metros do reservatório. .......................................................................21 Figura 5: Classificação manual do uso e cobertura da terra na área de 1000 metros no entorno do reservatório. 22 Figura 6: (A) Recorte da Imagem Landsat de 2014 (composição R: banda 6, G: banda 5, B: banda 4); (B) Classificação manual; (C) Classificação supervisionada SVM-linear. Em que: azul=água, verde $=$ cerradão, bege=cerrado, vermelho=agropecuária e amarelo=queimada.....29 Figura 7: Classificação temporal do uso e cobertura da terra para os 8 municípios analisados.

Figura 8: Evolução percentual do uso e cobertura da terra para os oito municípios analisados.

Figura 9: Exemplo de área modificada de Agropecuária para Cerradão (Reflorestamento). (A) Classificação na imagem de 2006; (B) Classificação da imagem de 2010; (C) Imagem do Google Earth de 2006; (D) Imagem do Google Earth de 2010 ........................................... 31 Figura 10: Evolução do uso e ocupação da terra para a área do buffer de 1000 metros ao longo da barragem.

Figura 11: Evolução do uso e cobertura da terra para a área de APP de 100 metros no entorno do reservatório. 


\section{Lista de Tabelas}

Tabela 1: Área, densidade demográfica e população da área de estudo.................................. 13

Tabela 2: Acervo de imagens de satélite utilizadas.............................................................. 17

Tabela 3: Cobertura e uso da terra na área teste (entorno do reservatório) em 2014..............23

Tabela 4: Acurácia e Índice Kappa (matriz de confusão a partir da classificação manual).....24 Tabela 5: Percentual de pixels classificados na comparação da matriz de confusão Imagem X

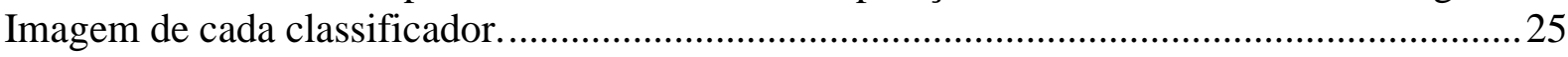

Tabela 6: Matriz de confusão do classificador SVM (linear)...............................................25

Tabela 7: Erros de comissão e omissão da classificação SVM (linear). ..................................26

Tabela 8: Matriz de confusão do classificador SVM (polinomial). ..........................................26

Tabela 10: Matriz de confusão do classificador SAM (none)...............................................27

Tabela 11: Matriz de confusão da classificação SVM (linear, após reagrupamento) ...............28

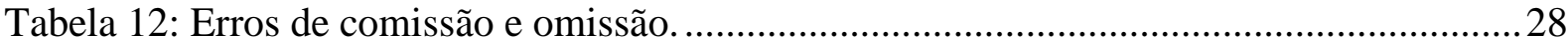




\section{Lista de Abreviaturas e Siglas}

AGMA Agência Goiana de Meio Ambiente

ANEEL Agência Nacional de Energia Elétrica

APP

Área de Preservação Permanente

ASTER

Advanced Spaceborne Thermal Emission and Reflection Radiometer

CAR

Cadastro Ambiental Rural

CONAMA Conselho Nacional do Meio Ambiente

DAIS Digital Airborne Imaging System

DP3 Desvio Padrão igual a 3

ENVI Environment for Visualizing Images

ETM+ Enhanced Thematic Mapper Plus

IBAMA Instituto Brasileiro do Meio Ambiente e dos Recursos Naturais Renováveis

IBGE Instituto Brasileiro de Geografia e Estatística

IMB Instituto Mauro Borges de Estatísticas e Estudos Socioeconômicos

KW Quilowatt

LANDSAT Land Remote Sensing Satellite

LP Licença Prévia

MaxVer Máxima Verossimilhança

MODIS/NDVI Moderate Resolution Imaging Spectroradiometer/Normalized Difference

Vegetation Index

OLI Operational Land Imager

ONU Organização das Nações Unidas

PACUERA Plano Ambiental de Conservação e Uso do Entorno do Reservatório

Artificial

SAM Spectral Angle Mapper

SID Spectral Information Divergence

SIG Sistema de Informação Geográfica

SV Single Value

SVM Support Vector Machine

TAC Termo de Ajustamento de Conduta 
TIRS

TM

TWh

UHE

USGS
Thermal Infrared Sensor

Thematic Mapper

Terawatt/hora

Usina Hidrelétrica

United States Geological Survey 


\section{INTRODUÇÃO}

O Brasil ocupa posição de destaque no cenário mundial na geração elétrica a partir de fontes renováveis, em especial, pela energia hidráulica, reflexo do grande potencial hídrico do Brasil (Guerra et al., 2015). Em 2014, as fontes renováveis representavam 76,6\% da oferta interna de eletricidade no país, somente a hidráulica correspondia a 65,2\% dessa oferta (Brasil, 2015a). No mesmo ano, a capacidade total instalada de geração de energia elétrica no país chegou a $133.914 \mathrm{MW}$, sendo que a energia hidrelétrica contribuiu para este total com 89.193 MW (Brasil, 2015a).

A estimativa de crescimento de consumo, a ser atendido pelo Sistema Elétrico Nacional, indica que a demanda passará de 463 TWh em 2013 para 1.495 TWh em 2050; essa projeção indica crescimento de 3,2\% ao ano (Brasil, 2015b).

Em resposta à demanda crescente, existe atualmente quantidade expressiva de projetos do governo federal que preveem a construção de hidrelétricas nos próximos anos para atender a demanda futura do país por energia. Segundo dados da Agência Nacional de Energia Elétrica (ANEEL), o Brasil possui 4.495 empreendimentos em operação, totalizando 142.556.350 KW de potência instalada. Está prevista para os próximos anos uma adição de 39.015.832 KW na capacidade de geração do país, proveniente dos 220 empreendimentos atualmente em construção e mais 623 de empreendimentos com construção não iniciada (ANEEL, 2016).

Diante da perspectiva de criação de novas usinas, cresce a preocupação sobre os diversos impactos ambientais negativos passíveis de ocorrerem, como o desmatamento de grandes áreas, afugentamento de fauna, eliminação de ecossistemas naturais, bloqueio da migração de peixes que afeta a biodiversidade, a produção comercial e a subsistência da população, mudança nos regimes de inundação à jusante, aumento da erosão fluvial, alteração no fluxo de sedimentos, aumento da emissão de metano em decorrência da presença de água anóxica no fundo dos reservatórios, migrações em massa e atração de atividades econômicas que por sua vez acarretam novos desmatamentos e mudanças no uso da terra (Fearnside, 2014, 2013).

Outros impactos estão relacionados com o aumento da intrusão de água salina na região localizada junto à foz, perda da conectividade entre os rios, desestabilização da base das encostas, modificação do fluxo e regime de sedimentos, impacto em áreas prioritárias para 
a conservação, alteração na qualidade da água, aumento da erosão fluvial e deslocamento de populações ribeirinhas (Kibler e Tullos, 2013; Kuenzer et al., 2013).

Os impactos ambientais provocados pelos reservatórios de usinas hidrelétricas demandam a atuação das autoridades ambientais brasileiras para a fiscalização da preservação da cobertura e do uso da terra no seu entorno, em especial a verificação do cumprimento do Código Florestal Brasileiro (Lei $\mathrm{n}^{\mathrm{o}}$ 12.651, de 25 de maio de 2012), no que diz respeito à preservação das Áreas de Preservação Permanente (APPs).

Nesse contexto, o sensoriamento remoto, associado a sistemas de informações geográficas (SIG), representa ferramenta importante para a identificação e mapeamento das mudanças ocorridas, sendo útil ao Estado na gestão do território e do ambiente (Chaves et al., 2013; Jensen, 2009; Redivo et al., 2003). O mapeamento destas mudanças por meio do sensoriamento remoto é feito normalmente com o uso de classificadores automatizados (Crósta, 1992; Jensen, 2009; Moreira, 2011). Dentre as classificações existentes, a supervisionada é a que mais se destaca dentre os demais tipos (Richards e Jia, 2006; Sarmiento et al., 2014). Neste intuito, alguns trabalhos têm sido desenvolvidos, em diferentes áreas de estudo, testando os diversos classificadores existentes para identificar aquele que obtém a melhor acurácia (Abburu e Babu Golla, 2015; Niknejad et al., 2014; Sarmiento et al., 2014).

Diante deste cenário, a presente pesquisa tem como objetivo identificar o método de classificação supervisionada mais adequado para o mapeamento de uso e cobertura da terra das áreas no entorno dos reservatórios de água construídos para a geração de energia elétrica. Para tanto, a Usina Hidrelétrica (UHE) de Corumbá IV e seu entorno, em Goiás, foram selecionados para a realização de testes utilizando os classificadores supervisionados Máxima Verossimilhança (MaxVer), Mínima Distância, Distância Mahalanobis, Paralelepípedo, Spectral Angle Mapper (SAM), Support Vector Machine (SVM) e Sector Information Divergence (SID).

Após a seleção do classificador de melhor desempenho para a área, foi feito mapeamento multitemporal, entre 1988 e 2015, do uso e cobertura da terra nos municípios do entorno do reservatório, visando identificar as modificações na paisagem ocorridas com a implantação do reservatório, principalmente, o estado de preservação da APP demandada no Código Florestal (Lei no 12.651/12) e da Resolução CONAMA no 302, de 20 de março de 2002. Os municípios foram escolhidos como unidade de análise, em detrimento da bacia 
hidrográfica, por ser essa a metodologia adota pelo Instituto Brasileiro do Meio Ambiente e dos Recursos Naturais Renováveis (Ibama), responsável pelo licenciamento da UHE de Corumbá IV (Ibama, 2016). Foi selecionada série temporal com oito anos (1988, 1998, 2005, 2006, 2008, 2010, 2014 e 2015).

A área adjacente ao reservatório da UHE de Corumbá IV e a dinâmica da comunidade local vêm sofrendo mudanças intensas desde o término do seu enchimento (Corumbá Concessões, 2014). Nesse contexto, diversas ocupações voltadas à exploração de atividades turísticas e de segunda residência surgiram de maneira desordenada na região. Considerando a importância hídrica do reservatório, entende-se ser necessária a compreensão do processo de ocupação da área e do atual estado do uso e cobertura da terra. 


\section{REVISÃO TEÓRICA}

\subsection{Classificação Automatizada de Imagens de Satélite}

A classificação é o processo de agrupamento dos pixels de uma imagem em categorias estabelecidas e pode ser feita de maneira manual, automática ou híbrida (Abburu e Babu Golla, 2015). A classificação automática é muito utilizada devido à maior rapidez, principalmente quando se trabalha em grandes áreas (Crósta, 1992). A classificação automática pode ser dividida em supervisionada e não supervisionada (Crósta, 1992; Abburu e Babu Golla, 2015). A primeira necessita que amostras sejam selecionadas e atribuídas a classes; na segunda, o próprio algoritmo cria as classes sem a necessidade de seleção de amostras (Moreira, 2011).

A classificação supervisionada é o procedimento mais utilizado para a classificação de imagens de sensoriamento remoto (Richards e Jia, 2006; Sarmiento et al., 2014). Dentre os classificadores supervisionados mais utilizados na literatura, destacam-se: Máxima Verossimilhança (MaxVer), Mínima Distância, Distância de Mahalanobis, Método do Paralelepípedo, Spectral Angle Mapper (SAM), Support Vector Machine (SVM) e Spectral Information Divergence (SID).

O MaxVer é o classificador mais comumente utilizado em sensoriamento remoto (Richards e Jia, 2006). Ele calcula a probabilidade de um determinado pixel pertencer a uma classe específica, partindo do pressuposto que as estatísticas para cada classe em cada banda são normalmente distribuídas (distribuição Gaussiana); todos os pixels são classificados e cada um é atribuído à classe que tem a maior probabilidade de pertencer, a menos que seja selecionado um limite de probabilidade (Envi, 2004). Este classificador é considerado um dos que costumam apresentar acurácia mais alta entre os métodos existentes (Niknejad et al., 2014).

O método da Mínima Distância calcula a média dos pixels de cada amostra. Em seguida, calcula-se a distância euclidiana entre todas as médias encontradas nas amostras de uma classe, definindo, assim, o seu valor médio. Por fim, a classificação coloca cada pixel na classe com valor mais próximo (mínima distância). Todos os pixels são classificados para a classe mais próxima, a menos que um desvio padrão ou distância padrão seja especificado, caso em que alguns pixels podem ser não classificados se eles não cumprirem os critérios 
selecionados (Envi, 2004). É um método mais rápido que o MaxVer, porém tem como desvantagem, quando comparado a este, o fato de não ser tão flexível, uma vez que não utiliza covariância; assim as amostras são tratadas como simétricas, aquelas alongadas, por exemplo, não serão adequadamente modeladas (Richards e Jia, 2006).

O método da Distância Mahalanobis é um classificador similar ao de Mínima Distância, porém incorpora a covariância, nele é considerada a dispersão dos dados (Niknejad et al., 2014; Richards e Jia, 2006).

O método do Paralelepípedo utiliza as informações dos histogramas de cada componente espectral da amostra, identificando os valores mínimos e máximos para cada banda. Os valores identificados formam um retângulo multidimensional (paralelepípedo). Os pixels encontrados dentro dos valores do paralelepípedo são então classificados como pertencentes à classe. É considerado um método simples, contudo, apresentam inconvenientes como o fato de não classificar as lacunas formadas no paralelepípedo e não conseguir separar as áreas de sobreposição de polígonos de classes diferentes (Richards e Jia, 2006).

O método SAM determina a similaridade espectral entre dois espectros e em seguida calcula o ângulo entre eles, considerados como vetores num espaço n-dimensional. O valor obtido é usado como medida de discriminação para atribuir os pixels a uma determinada classe ( Du et al., 2004; Kruse et al., 1993).

O SVM é um método de classificação não paramétrico, ou seja, não há suposição sobre a forma de distribuição dos dados (Jensen, 2009; Mountrakis et al., 2011), não sofrendo, dessa maneira, as limitações geradas pela dimensionalidade dos dados (Srivastava et al., 2010). O SVM procura separar as classes através de um procedimento otimizado que encontra elementos que formam os limites entre as classes (Gualtieri e Cromp, 1998). Tem sido considerado como tendo bom desempenho de acurácia em relação aos outros classificadores (Niknejad et al., 2014; Srivastava et al., 2010).

O método SID é um método de classificação que usa uma medida de divergência para associar o pixel a um determinado espectro. Quanto menor a divergência, maior a probabilidade de o pixel pertencer a uma classe. Os pixels com valores angulares superiores que o limite máximo especificado não são classificados (Du et al., 2004). 


\section{2. Áreas de Preservação Permanente}

\subsubsection{Código Florestal}

O Código Florestal Brasileiro (Lei no 12.651, de 25 de maio de 2012) é o instrumento que apresenta a definição jurídica de Área de Preservação Permanente (APP) além de estabelecer "normas gerais sobre a proteção da vegetação, Áreas de Preservação Permanente e as áreas de Reserva Legal; a exploração florestal, o suprimento de matéria-prima florestal, o controle da origem dos produtos florestais e o controle e prevenção dos incêndios florestais, e prevê instrumentos econômicos e financeiros para o alcance de seus objetivos" (Art. $1^{\mathrm{o}}$-A) (Brasil, 2012).

Segundo essa legislação, as "florestas existentes no território nacional e as demais formas de vegetação nativa, reconhecidas de utilidade às terras que revestem, são bens de interesse comum a todos os habitantes do País" (Art. $2^{\circ}$ ).

De acordo com o Código Florestal, APP é a "área protegida, coberta ou não por vegetação nativa, com a função ambiental de preservar os recursos hídricos, a paisagem, a estabilidade geológica e a biodiversidade, facilitar o fluxo gênico de fauna e flora, proteger o solo e assegurar o bem-estar das populações humanas" (Art. $2^{\circ}$, II).

Essa Lei elenca as feições consideradas como APP, entre elas estão "as áreas no entorno dos reservatórios d'água artificiais, decorrentes de barramento ou represamento de cursos d'água naturais, na faixa definida na licença ambiental do empreendimento" (Art. $4^{\circ}$, III). Dessa maneira, os reservatórios construídos visando a geração de energia elétrica devem ter nas suas margens uma faixa de vegetação preservada com o objetivo de atender ao disposto na legislação.

Para tanto, o Código Florestal atribui aos empreendedores dos reservatórios d'água artificiais, destinados à geração de energia ou abastecimento público, a responsabilidade de promover a aquisição, desapropriação ou instituição de servidão administrativa das APPs criadas no entorno do reservatório, respeitando a faixa mínima de 30 (trinta) metros e máxima de 100 (cem) metros em área rural e mínima de 15 (quinze) metros e máxima de 30 (trinta) metros em área urbana (Art. $5^{\circ}$ ). Os valores exatos estão previstos para serem estabelecidos no âmbito do licenciamento ambiental, considerando as particularidades da área atingida, da obra e do bioma afetado. 
O Código Florestal trata ainda da possibilidade do entorno do reservatório adquirir outros usos, contudo esses não poderão exceder $10 \%$ do total da APP, e deverão estar previstos do Plano Ambiental de Conservação e Uso do Entorno do Reservatório elaborado pelo empreendedor, sob orientação de um termo de referência emitido pelo órgão licenciador (Art. $\left.5^{\circ}, \S 1^{\circ}\right)$.

Sobre o regime de proteção das APPs, a Lei afirma que a vegetação situada em APP deverá ser mantida pelo proprietário da área, possuidor ou ocupante a qualquer título, pessoa física ou jurídica, de direito público ou privado (Art. $7^{\circ}$ ).

A Lei prevê que "tendo ocorrido supressão de vegetação situada em Área de Preservação Permanente, o proprietário da área, possuidor ou ocupante a qualquer título é obrigado a promover a recomposição da vegetação, ressalvados os usos autorizados previstos nesta Lei”. Prevê também que no caso de supressão não autorizada de vegetação realizada após 22 de julho de 2008, é vedada a concessão de novas autorizações de supressão de vegetação, enquanto não cumpridas às obrigações de recomposição $\left(\S 1^{\circ}\right.$ e $3^{\circ}$ Art. $\left.7^{\circ}\right)$.

Importante destacar a previsão da Lei acerca das atividades agrossilvipastoris, de ecoturismo e de turismo rural em áreas rurais consolidadas, definidas como APP, até 22 de julho de 2008, onde será autorizada, exclusivamente, a continuidade das atividades (Art. 61A). Da mesma forma, será admitida a manutenção de residências e da infraestrutura associada às atividades agrossilvipastoris, de ecoturismo e de turismo rural, inclusive o acesso a essas atividades desde que não estejam em área que ofereça risco à vida ou à integridade física das pessoas ( $\$ 12$, Art. 61-A).

\subsubsection{Resolução Conama n ${ }^{o} 302 / 2002$}

A Resolução CONAMA n ${ }^{\circ}$ 302, de 20 de março de 2002, estabelece os parâmetros, definições e limites de APPs para o entorno de reservatórios artificiais, estabelece o regime de uso do entorno e torna obrigatória a criação de um Plano Ambiental de Conservação e Uso do Entorno dos Reservatórios Artificiais (PACUERA) (Brasil, 2002).

Segundo o Art. 3 desta resolução: 
“Art $3^{\circ}$ Constitui Área de Preservação Permanente a área com largura mínima, em projeção horizontal, no entorno dos reservatórios artificiais, medida a partir do nível máximo normal de:

I - trinta metros para os reservatórios artificiais situados em áreas urbanas consolidadas e cem metros para áreas rurais;

II - quinze metros, no mínimo, para os reservatórios artificiais de geração de energia elétrica com até dez hectares, sem prejuízo da compensação ambiental;

III - quinze metros, no mínimo, para reservatórios artificiais não utilizados em abastecimento público ou geração de energia elétrica, com até vinte hectares de superfície e localizados em área rural."

A Resolução prevê a possibilidade da área no entorno ter usos turísticos e de lazer, contudo esse uso deve ser previsto no PACUERA e não poderão exceder a 10\% da área total do entorno do reservatório (Art. $4^{\circ}, \S 4^{\circ}$ ).

\subsubsection{Política Florestal do Estado de Goiás (Lei $n^{o}$ 18.104/2013)}

A Lei 18.104, de 18 de julho de 2013, estabelece as normas sobre a proteção da vegetação, dispõe sobre as APPs e as áreas de Reserva Legal, define regras sobre a exploração florestal, cria o Cadastro Ambiental Rural (CAR) do Estado de Goiás e prevê programas de incentivo para o alcance de seus objetivos (Art. $1^{\circ}$ ) (Goiás, 2013).

O conteúdo desse instrumento legal complementa o Código Florestal Brasileiro e em muitos itens reproduz o mesmo conteúdo, considera como APP as áreas no entorno dos reservatórios d'água artificiais, na faixa definida na licença ambiental do empreendimento (III, Art. $9^{\circ}$ ).

De acordo com o Art. 10:

"na implementação ou funcionamento de reservatório d'água artificial destinado à geração de energia ou abastecimento público, é obrigatória a aquisição, desapropriação ou remuneração por restrição de uso, bem como a compensação e a recomposição da área inundada pelo empreendedor, das áreas de preservação permanente criadas em seu entorno, conforme estabelecido no licenciamento, observando-se a faixa mínima de 30 (trinta) metros e máxima de 100 (cem) metros em área rural, e a faixa mínima de 15 (quinze) metros em área urbana" (Art. 10).

Sobre as atividades existentes nas APPs em áreas rurais consolidadas antes de 22 de julho de 2008, a Lei autoriza a continuidade daquelas relacionadas a atividades 
agrossilvipastoris, de ecoturismo e de turismo rural (Art. 13). O mesmo é feito para as residências associadas a essas atividades, desde que não estejam em área que comprovadamente ofereça risco à vida ou à integridade física das pessoas (Art. 18).

\subsection{Licenciamento Ambiental da Usina e do Reservatório}

O processo de licenciamento ambiental do empreendimento teve início na Agência Goiana de Meio Ambiente e Recursos Naturais em 1998. Esse órgão emitiu no ano seguinte a Licença Prévia de Instalação no 017/99. Contudo, em virtude de demanda judicial, o processo passou a ser conduzido pelo Ibama, a partir de setembro de 2004. Em 15 de abril de 2004, foi celebrado Termo de Ajuste de Conduta (TAC) entre o Ministério Público Federal, o Ibama e a Corumbá Concessões S.A., relativo à Ação Civil Pública n 2002.35.00.011863-2, que continha os termos do licenciamento ambiental a serem atendidos a partir de então pelo empreendedor (Ibama, 2010).

Contudo, apesar da assinatura do TAC, ao longo do processo de licenciamento foram verificados descumprimentos de condicionantes estabelecidas pelo órgão ambiental federal, que visavam garantir e resguardar as condições de sobrevivência digna da população diretamente afetada pelo empreendimento. Foi constatado na época o "risco de geração irreversível de um grande ônus social em decorrência dos procedimentos equivocados ou insuficientemente adotados em relação ao trato com as questões socioeconômicas" (Ibama, 2010).

Entre as condicionantes de validade da licença ainda não executadas está a realização do PACUERA - exigido pela Resolução CONAMA nº 302, de 20 de março de 2012 apresentado duas vezes ao Ibama e considerado inadequado nas duas ocasiões. A exigência ainda está presente na atual Licença de Operação do empreendimento (renovada em 26 de março de 2014, com validade de seis anos) para ser implantada pela empresa Corumbá Concessões (Ibama, 2014).

Os estudos iniciais sobre a área, onde posteriormente foi instalada a UHE de Corumbá IV, tiveram início em dezembro de 1998. Foi realizado inventário ambiental da bacia do Alto Corumbá tendo este sido aprovado em 23 de setembro de 2009 pela ANEEL (Corumbá Concessões, 2014). 
Em dezembro de 1999, a Agência Ambiental de Goiás (AGMA) emitiu a Licença Ambiental Prévia (LP) para o empreendimento e em abril do ano seguinte ocorreu a submissão da UHE a processo de leilão que concedeu o uso da Usina como bem público para exploração energética (Corumbá Concessões, 2014).

Em janeiro de 2001 tiveram início as obras, perdurando até fevereiro de 2006 quando ocorreu a inauguração e início da geração de energia (Corumbá Concessões, 2014).

O reservatório foi construído a partir do represamento do Rio Corumbá, que é divisa natural entre os municípios goianos de Abadiânia, Alexânia, Corumbá de Goiás, Gameleira de Goiás, Luziânia, Novo Gama, Santo Antônio do Descoberto e Silvânia. A lâmina d'água do reservatório tem extensão de $173 \mathrm{~km}^{2}$ e perímetro de 783,7 km. Segundo informações da empresa, a APP ultrapassa 9.000 hectares (Corumbá Concessões, 2014).

A Corumbá Concessões apresentou ao Ibama, em julho de 2011, versão revisada do PACUERA da UHE de Corumbá IV em atendimento ao disposta na Resolução CONAMA n ${ }^{\circ}$ 302, de março de 2002, que estabelece os parâmetros, definições e limites de APP de reservatórios artificiais e o regime de uso do entorno e que tornou obrigatória a elaboração desse instrumento de gestão ambiental (Ibama, 2010).

Para a realização deste documento, a Corumbá Concessões usou como base, entre outras referências, a elaboração de diagnóstico participativo com as comunidades adjacentes ao reservatório e consultas aos planos diretores municipais quando existentes. O documento apresenta para cada município, a quantidade de interferências encontradas na APP (acessos, casas, loteamentos, erosões, praias, pastos, etc.), contudo, não apresenta mapeamentos de uso e ocupações atuais da terra e da proposta do PACUERA propriamente, não sendo possível visualizar as informações apresentadas sobre as categorias estabelecidas, que foram as Macrozonas:

- Zona Lacustre, dividida em duas microzonas: Zona Lacustre de Segurança e Zona Lacustre de Lazer;

- Zona de Preservação, dividida em Zona de Preservação - APP, Zona de Preservação Unidade de Conservação, Zona de Preservação da Cultura Tradicional, Zona de Preservação e Ocupação;

- Zona de Ocupação, dividida em duas microzonas: Zona de Ocupação Orientada e Zona de Ocupação - Corredores de Serviços; e

- Zona Rural, constituída da Zona Rural Especial. 
O PACUERA elaborado pela Corumbá Concessões não informa o percentual de APP existente nem o percentual da terra ocupado por outros usos, com também não possui o caráter de planejamento, conforme indicado pela Resolução CONAMA n 302/12 (Ibama, 2010) 


\section{CARACTERIZAÇÃO DA ÁREA DE ESTUDO}

A UHE de Corumbá IV está instalada no rio Corumbá e seu reservatório ocupa uma área de $173 \mathrm{~km}^{2}$ e perímetro de 783,4 km. Essa usina entrou em funcionamento em 4 de abril de 2006, com capacidade instalada de 129,6 MW, destinada ao abastecimento elétrico de parte do Distrito Federal, sendo capaz de atender uma população de 250 mil habitantes. O reservatório é considerado de uso múltiplo, ou seja, além da geração de energia, suas águas podem ser usadas para atividades de lazer e abastecimento humano (Corumbá Concessões, 2014).

A área de abrangência do estudo corresponde ao entorno do reservatório, composta pelos oito municípios diretamente afetados pela barragem: Abadiânia, Alexânia, Corumbá de Goiás, Gameleira de Goiás, Luziânia, Novo Gama, Santo Antônio do Descoberto e Silvânia (Figura 1).
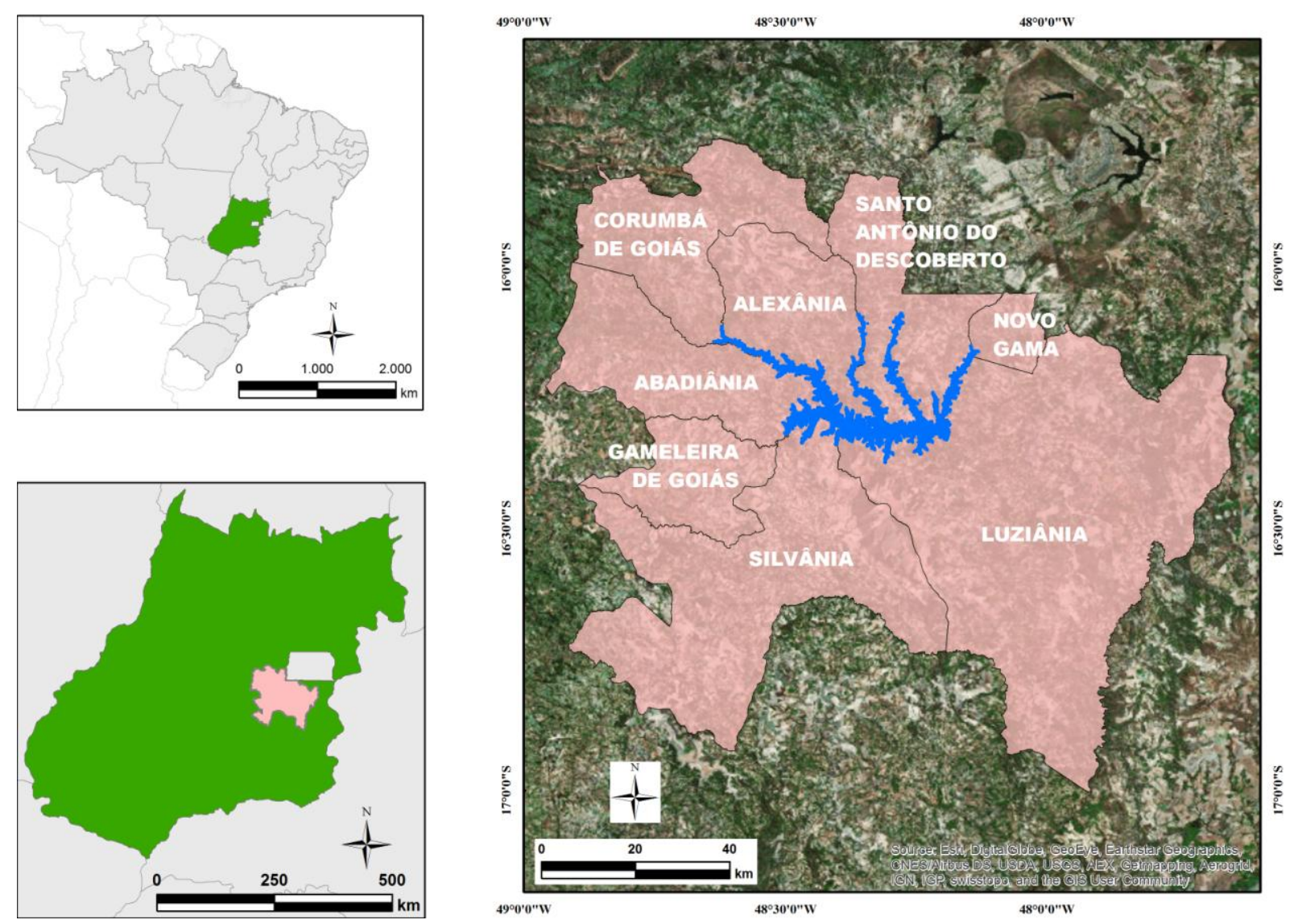

$48^{\circ} 30^{\circ} 0^{\prime \prime} \mathrm{V}$

$48^{\circ} 0^{\prime} 0^{\prime \prime} \mathrm{W}$

Figura 1: Mapa de localização da área de estudo. 
Os municípios da área de estudo localizam-se em duas microrregiões geográficas: Entorno de Brasília (Abadiânia, Alexânia, Corumbá de Goiás, Luziânia, Novo Gama, Santo Antônio do Descoberto) e Pires do Rio (Gameleira de Goiás e Silvânia). Possui uma área de $10.993,161 \mathrm{~km}^{2}$ e uma população de aproximadamente 405.093 habitantes, de acordo com o último censo demográfico (IBGE, 2010) (Tabela 1).

O reservatório de Corumbá IV (Figura 1) atinge os municípios da seguinte maneira: Abadiânia (divisa leste), Alexânia (porção sul), Corumbá de Goiás (pontualmente no extremo sul), Gameleira de Goiás (com a menor área inundada pelo reservatório, atinge a porção nordeste), Luziânia (divisa noroeste), Novo Gama (porção sudoeste), Silvânia (divisa norte) e Santo Antônio do Descoberto (maior área inundada dentre os demais municípios, nas divisas sul, sudeste, sudoeste e porção central).

Tabela 1: Área, densidade demográfica e população da área de estudo (Fonte: IBGE, 2010).

\begin{tabular}{|c|c|c|c|c|}
\hline \multirow[t]{2}{*}{ Município } & \multirow[t]{2}{*}{ Área $\left(\mathrm{km}^{2}\right)$} & \multirow{2}{*}{$\begin{array}{c}\text { Densidade } \\
\text { Demográfica } \\
\text { média }\left(\mathrm{hab} / \mathrm{km}^{2}\right)\end{array}$} & \multicolumn{2}{|c|}{ População (hab.) } \\
\hline & & & 2010 & 2014 (estim.) \\
\hline Abadiânia & $1.045,127$ & 15,08 & 15.757 & 17.701 \\
\hline Alexânia & 847,893 & 28,09 & 23.814 & 25.805 \\
\hline Corumbá de Goiás & $1.061,955$ & 9,76 & 10.361 & 10.896 \\
\hline Gameleira de Goiás & 591,995 & 5,53 & 3.275 & 3.605 \\
\hline Luziânia & $3.961,122$ & 44,06 & 174.531 & 191.139 \\
\hline Novo Gama & 194,992 & 487,29 & 95.018 & 104.899 \\
\hline $\begin{array}{l}\text { Santo Antônio do } \\
\text { Descoberto }\end{array}$ & 944,137 & 66,99 & 63.248 & 69.000 \\
\hline Silvânia & $2.345,940$ & 8,14 & 19.089 & 20.106 \\
\hline $\begin{array}{l}\text { Total da Área de } \\
\text { Estudo }\end{array}$ & $10.993,161$ & 83,11 & 405.093 & 443.151 \\
\hline Total do Estado & $340.111,376$ & 17,65 & 6.003 .788 & 6.523 .222 \\
\hline
\end{tabular}

A área de estudo está localizada na zona climática Tropical Brasil Central com predominância do clima subquente (média entre $15^{\circ} \mathrm{C}$ e $18{ }^{\circ} \mathrm{C}$ em pelo menos um mês) semiúmido com quatro a cinco meses secos. A precipitação acumulada para o ano de 2012 na 
área de estudo é descrita em duas classes, de 1.200,01 mm até $1.400 \mathrm{~mm}$ na porção oeste e de $1.000,01 \mathrm{~mm}$ e até $1.200 \mathrm{~mm}$, a leste (IMB, 2006).

Em relação à geologia, localiza-se em sequências metavulcanossedimentares e terrenos granito-gnáissicos (Cinturões Paleoproterozóicos) e nas bacias Marginal de Arco, de Margem Passiva e Zona Interna-raiz de Arcos Magmáticos (Faixa Brasília) (IMB, 2006). Em relação a solos, predominam os Latossolos e Cambissolos, além de Argissolos e Gleissolos (IMB, 2006).

Quanto ao relevo, a área de estudo está localizada na unidade geomorfológica do Planalto do Alto Tocantins-Paranaíba, na região do Planalto Central Goiano. Essa região subdivide-se em cinco unidades geomorfológicas (Complexo Montanhoso Veadeiros-Araí, Complexo Serrano Barro Alto-Serra Dourada, Chapada do Rio Maranhão, Planalto do Alto do Tocantins-Paranaíba e Planalto Divisor Araguaia-Tocantins-Paraná) e está inserida no Domínio dos Planaltos de Estruturas Dobradas. Nessa região, o arranjo da drenagem é consideravelmente influenciado pela tectônica e ocorre intensa dissecação em decorrência dos fatores lito-estruturais e climáticos (Lacerda Filho et al., 1999).

A área está inserida na sub-bacia do Rio Corumbá, que compõe a Bacia Hidrográfica do Rio Paranaíba, região hidrográfica do Paraná. A Bacia do Rio Paranaíba inclui parte do território de Goiás, Minas Gerais, Mato Grosso do Sul e Distrito Federal, é caracterizada pela importância na produção de energia hidrelétrica no cenário nacional e pela presença significativa da agropecuária (Ana, 2016).

Inserida no bioma Cerrado, a vegetação da área apresenta as seguintes fisionomias: Savana Parque (campo-sujo-de-cerrado), Savana Arborizada (Campo Cerrado, Cerrado "sentido restrito") e Savana/Floresta Estacional (IMB, 2006). Contudo, a vegetação nativa da área em estudo encontra-se parcialmente convertida em pastagens cultivadas e culturas agrícolas (Sano et al., 2008).

De acordo com o mapeamento de cobertura e uso da terra de 2011, elaborado pelo IMB para o Estado de Goiás, a área do presente estudo é formada por vegetação nativa de cerrado, agricultura, pastagem e, em menor proporção, por áreas urbanizadas. Nas margens do reservatório, não foram identificadas áreas urbanas, predominando o cerrado e as pastagens (IMB, 2006). 


\section{MATERIAIS E MÉTODOS}

A Figura 2 apresenta o fluxograma dos procedimentos metodológicos adotados, que podem ser subdivididos em duas partes: (a) análise comparativa dos métodos de classificação supervisionada, e (b) análise multitemporal do uso e cobertura da terra nos oito municípios adjacentes ao reservatório da UHE de Corumbá IV.

A seleção do método de classificação supervisionada para a área de estudo considerou os resultados de sete classificadores usando uma imagem Landsat-8/Operational Land Imager (OLI) em comparação com uma classificação manual feita a partir da mesma imagem Landsat e com o auxílio de imagens Rapideye e do programa Google Earth. O método que apresentou a melhor acurácia foi adotado para a classificação das imagens multitemporais, considerando dados do Landsat-5/Thematic Mapper (TM) e Landsat-8/OLI. Os resultados das classificações foram utilizados na descrição da evolução do uso e cobertura da terra dos municípios analisados e na identificação da presença da APP nas margens do reservatório.

\section{Análise Comparativa entre os Métodos de Classificação Supervisionada}

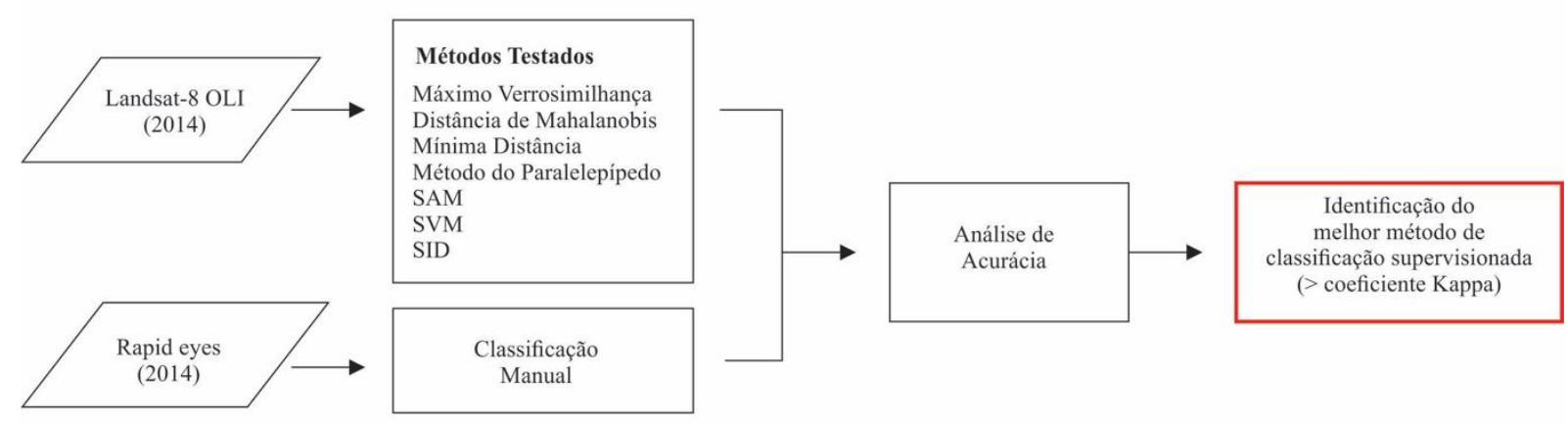

\section{Análise Multitemporal}

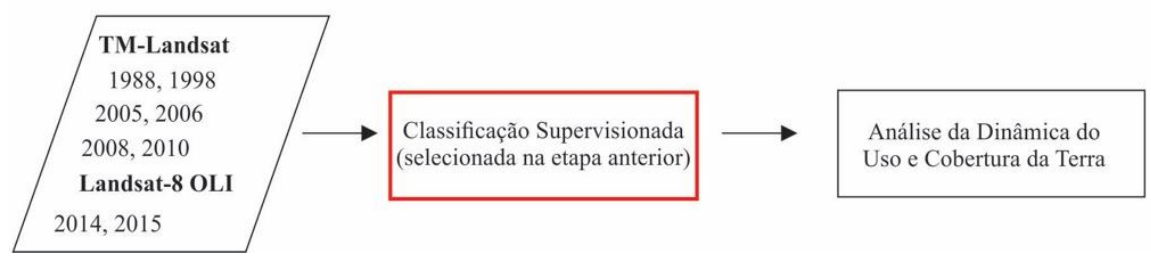

Figura 2: Fluxograma dos procedimentos metodológicos. 


\subsection{Dados de Sensoriamento Remoto}

Nesta pesquisa foram utilizados dados de sensoriamento remoto oriundos dos satélites Landsat-5/TM, Landsat-8/OLI e RapidEye. No Landsat-5, o sensor TM gera imagens com sete bandas espectrais com resolução espacial de 30 metros para as bandas de 1 a 5 e 7 e de 120 metros para a banda 6 (infravermelho termal, não utilizada no presente estudo). Cada cena tem aproximadamente 120 quilômetros (sentido norte/sul) por 183 quilômetros (leste/oeste). As bandas possuem comprimentos de ondas equivalentes a (em $\mu \mathrm{m}): 0,45-0,52$ (banda 1); 0,52-0,60 (banda 2); 0,63-0,69 (banda 3); 0,76-0,90 (banda 4); 1,55-1,75 (banda 5); 10,40-12,50 (banda 6); 2,08-2,35 (banda 7) (USGS, 2016).

O sensor OLI do Landsat- 8 gera imagens constituídas por nove bandas espectrais com resolução espacial de 30 metros para as bandas de 1 a 7 e 9, e 15 metros de resolução para a banda 8. Cada cena tem aproximadamente 170 quilômetros (sentido norte/sul) por 183 quilômetros (leste/oeste). O Landsat-8 possui ainda o sensor Thermal Infrared Sensor (TIRS) que gera duas bandas termais (10 e 11), não utilizadas nesses estudo. As bandas possuem comprimentos de onda equivalentes a (em $\mu \mathrm{m}$ ): 0,43 - 0,45 (banda 1); 0,45 - 0,51 (banda 2); 0,53 - 0,59 (banda 3); 0,64 - 0,67 (banda 4); 0,85 - 0,88 (banda 5); 1,57 - 1,65 (banda 6); 2,11 - 2,29 (banda 7); 0,50 - 0,68 (banda 8); 1,36 - 1,38 (banda 9); 10,60 - 11,19 (banda 10); 11,50 - 12,51 (banda 11) (USGS, 2016).

Os satélites da constelação RapidEye geram imagens constituídas por cinco bandas espectrais, com 5 metros de resolução espacial. Cada imagem tem aproximadamente 77 quilômetros de largura com comprimento variando entre 50 e 300 quilômetros. As bandas possuem os seguintes comprimentos de onda equivalentes (em nm): 440 - 510 (banda Blue); 520 - 590 (banda Green); 630 - 685 (banda Red); 690 - 730 (Red-Edge); e 760 - 850 (Infravermelho Próximo) (BlackBridge, 2016). As imagens do RapidEye para o ano de 2014 foram obtidas no site do Ministério do Meio Ambiente (http://geocatalogo.mma.gov.br/). Foram usadas imagens dos dias 16 de março, 17, 25 e 29 de maio de 2014.

As imagens Landsat-5/TM (relativas aos anos de 1988, 1998, 2005, 2006, 2008 e 2010) e Landsat-8/OLI (relativas aos anos de 2014 e 2015), corrigidas dos efeitos atmosféricos (USGS, 2015a, 2015b), foram obtidas no site do United States Geological Survey (USGS) (http://landsat.usgs.gov/) (Tabela 2). As imagens foram adquiridas no período seco (entre junho e agosto) visando diminuir a interferência de nuvens e das mudanças 
sazonais da vegetação e da agricultura (Castro et al., 2013). O período de maio a outubro apresenta maior probabilidade de obtenção de imagens Landsat com menos de $10 \%$ de nuvens, de acordo com análise da série histórica (Sano et al., 2008). A área de estudo corresponde a três imagens, referentes às seguintes cenas (orbita/ponto): 221/71, 221/72 e 222/71. Os mosaicos de imagens de cada ano foram recortados conforme a área de estudo.

Tabela 2: Acervo de imagens de satélite utilizadas.

\begin{tabular}{|c|c|c|c|c|}
\hline \multicolumn{5}{|c|}{ Imagens de satélite disponibilizadas para consulta pública } \\
\hline Satélite & Ano & Órbita & Ponto & Data \\
\hline \multirow[t]{3}{*}{ Landsat-5/TM } & \multirow[t]{3}{*}{1988} & 221 & 71 & $24 / 07 / 88$ \\
\hline & & 221 & 72 & $24 / 07 / 88$ \\
\hline & & 222 & 71 & $31 / 07 / 88$ \\
\hline \multirow[t]{3}{*}{ Landsat-5/TM } & \multirow[t]{3}{*}{1998} & 221 & 71 & 04/07/98 \\
\hline & & 221 & 72 & 04/07/98 \\
\hline & & 222 & 71 & $11 / 07 / 98$ \\
\hline \multirow[t]{3}{*}{ Landsat-5/TM } & \multirow[t]{3}{*}{2005} & 221 & 71 & $23 / 07 / 05$ \\
\hline & & 221 & 72 & $23 / 07 / 05$ \\
\hline & & 222 & 71 & $14 / 07 / 05$ \\
\hline \multirow[t]{3}{*}{ Landsat-5/TM } & \multirow[t]{3}{*}{2006} & 221 & 71 & $24 / 06 / 06$ \\
\hline & & 221 & 72 & $24 / 06 / 06$ \\
\hline & & 222 & 71 & 01/07/06 \\
\hline \multirow[t]{3}{*}{ Landsat-5/TM } & \multirow[t]{3}{*}{2008} & 221 & 71 & $16 / 08 / 08$ \\
\hline & & 221 & 72 & $16 / 08 / 08$ \\
\hline & & 222 & 71 & 23/08/08 \\
\hline \multirow[t]{3}{*}{ Landsat-5/TM } & \multirow[t]{3}{*}{2010} & 221 & 71 & $05 / 07 / 10$ \\
\hline & & 221 & 72 & $05 / 07 / 10$ \\
\hline & & 222 & 71 & $12 / 07 / 10$ \\
\hline \multirow[t]{3}{*}{ Landsat-8/OLI } & \multirow[t]{3}{*}{2014} & 221 & 71 & $16 / 07 / 14$ \\
\hline & & 221 & 72 & $16 / 07 / 14$ \\
\hline & & 222 & 71 & $07 / 07 / 14$ \\
\hline \multirow[t]{3}{*}{ Landsat-8/OLI } & \multirow[t]{3}{*}{2015} & 221 & 71 & $04 / 08 / 15$ \\
\hline & & 221 & 72 & $04 / 08 / 15$ \\
\hline & & 222 & 71 & $11 / 08 / 15$ \\
\hline
\end{tabular}




\subsection{Análise Comparativa entre os Métodos de Classificação Supervisionada}

\subsubsection{Aplicação dos métodos de classificação supervisionada para a área teste}

No presente trabalho foram avaliados sete métodos de classificação supervisionada de imagens: Distância Mahalanobis, Máxima Verossimilhança (MaxVer), Mínima Distância, Paralelepípedo, Spectral Angle Mapper (SAM), Support Vector Machine (SVM) e Spectral Information Divergence (SID).

Nos classificadores Mínima Distância e Paralelepípedo, foram feitos testes com desvio padrão igual a 3 (DP3) e sem a inserção desse valor (none). Como descrito antes, o classificador de Mínima Distância utiliza valores médios da amostra coletada e os pixels são classificados conforme sua proximidade do valor da classe. Aplicando-se um desvio padrão é possível aumentar os valores que poderão ser classificados na amostra. O método do Paralelepípedo, como utiliza os valores máximos e mínimos dentro da amostra coletada, com o desvio padrão esses valores máximos e mínimos podem ser aumentados. No SAM foi feito teste adicional usando um ângulo máximo de 0,10 graus para todas as classes, com isso é possível aumentar o ângulo entre os espectros analisados da classe coletada e verificar se ocorrerá uma maior eficiência do classificador. No classificador SVM foram usados os quatro tipos Kernel disponíveis: linear, polinomial, sigmoidal e radial. Dessa maneira, foram feitas 14 classificações diferentes para a área de estudo.

Os métodos de classificação supervisionada foram aplicados nas imagens Landsat8/OLI referente ao ano de 2014. Para efeitos da análise de acurácia dos classificadores considerou-se somente a área teste relativa a um buffer de 1000 metros a partir da margem do reservatório (Figura 3).

\subsubsection{Análise de acurácia e definição do melhor método de classificação supervisionada}

$\mathrm{Na}$ análise de acurácia e determinação do melhor método de classificação supervisionada foi utilizada como dado de referência (imagem verdade) a classificação manual por interpretação visual feita a partir da Imagem Landsat-8/OLI de 2014. A interpretação visual foi auxiliada pela interpretação de imagens RapidEye e das imagens 
disponíveis no programa Google Earth. As imagens disponibilizadas pelo Google Earth apresentam alta resolução espacial, o que facilita a delimitação das classes de uso e cobertura da terra (Dorais e Cardille, 2011). A classificação manual foi realizada por meio de elementos de interpretação da imagem como cor, textura, forma, padrão, localização e contexto (Florenzano, 2011).

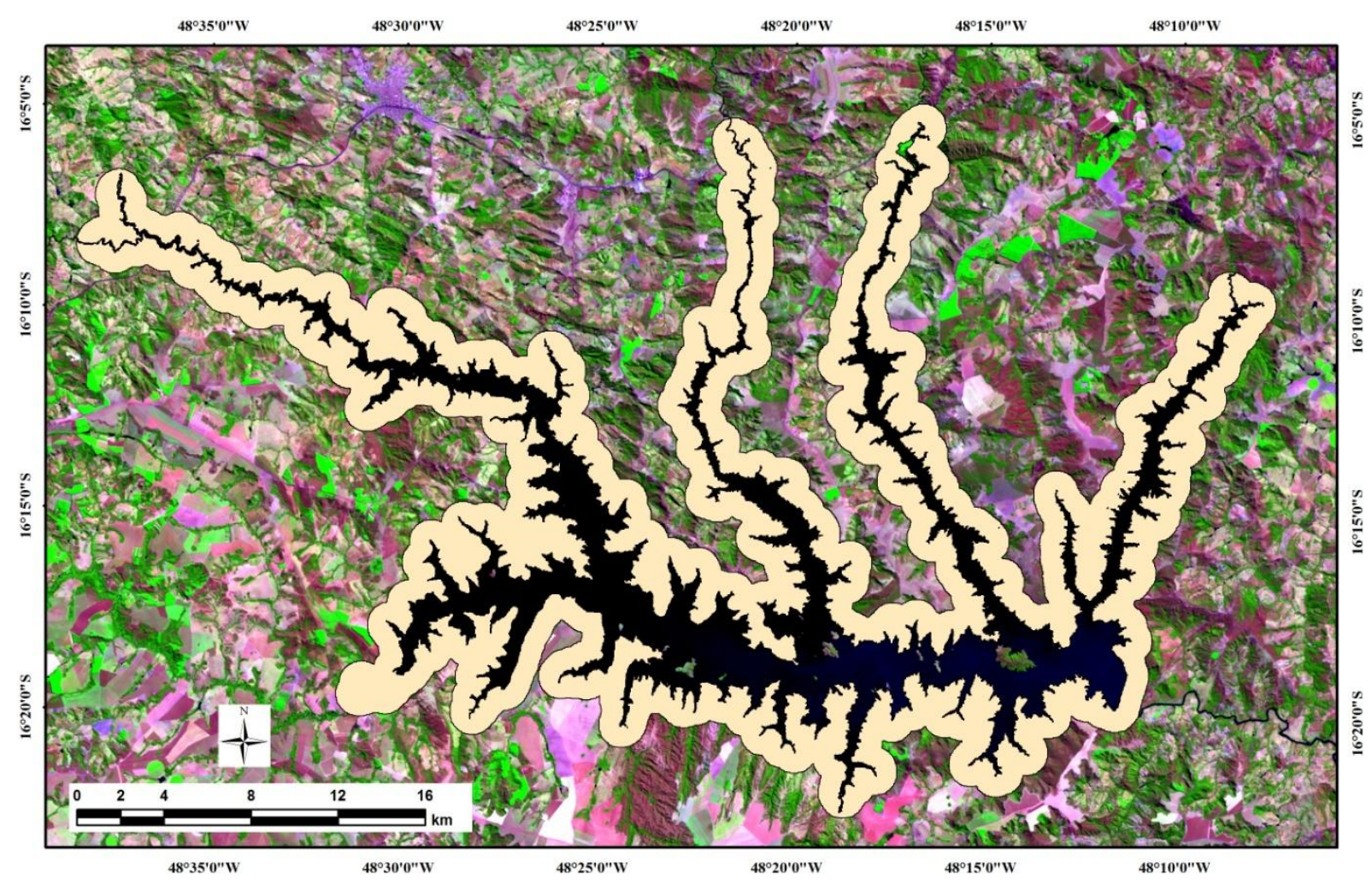

Figura 3: Área para o teste dos classificadores (buffer de 1000 metros a partir da margem do reservatório).

As classes de uso e cobertura da terra estabelecidas para a classificação manual foram: Agricultura, Pecuária, Cerradão (que incluiu também a mata de galeria), Cerrado (que incluiu também campo), Água (que inclui os rios e lagos no entorno), Edificações/Loteamentos (que incluiu também a estrutura da barragem e rodovias), Solo Exposto (que incluiu as estradas de terra), Queimada, Reflorestamento e Pivô.

Após a realização dos testes iniciais estas classes foram reagrupadas considerando as particularidades da imagem Landsat (resolução espectral e espacial) em: Agropecuária (que incluiu agricultura, pecuária, solo exposto, loteamentos, estradas, rodovias, estrutura da barragem e desmatamento), Cerradão (incluiu cerradão e reflorestamento), Cerrado, Água e Queimada. 
As queimadas foram mantidas como uma classe específica, assim como foi feito nos trabalhos de Grondona (2009) e Moreira e Assad (2000). Conforme Mantovani e Pereira (1998), as queimadas podem corresponder a áreas de cerrado, que posteriormente se regenerarão ou a áreas relacionadas a atividades agropecuárias. Já Almeida et al. (2011) consideraram as áreas de queimada como parte da área antropizada. A presente pesquisa optou por considerar uma classe específica uma vez que a identificação do uso original da área queimada demandaria análise visual de cada ocorrência presente ao longo da série temporal.

A análise de acurácia comparou as imagens classificadas pelos diferentes métodos e a imagem da classificação manual. A análise de acurácia utilizou matrizes de confusão, índice Kappa, erros de comissão e omissão e a acurácia do usuário e do produtor (Plourde e Congalton, 2003). A análise do índice Kappa considerou a conceituação estabelecida por Landis e Koch (1977), onde: < 0,0 (péssima), 0,0 - 0,2 (ruim), 0,2 - 0,4 (razoável), 0,4 - 0,6 (boa), 0,6 - 0,8 (muito boa), 0,8 - 1,0 (excelente).

\subsection{Análise Multitemporal do Uso e Cobertura da Terra nas APPs do Reservatório de Corumbá}

Após a seleção do melhor classificador, foram executadas as classificações para toda a área de estudo em todos os anos da análise. Posteriormente, as imagens (raster) geradas foram convertidas para o formato shapefile e a partir delas foram obtidos os dados de área de cada uma das classes identificadas. A tabulação destes dados permitiu a identificação do percentual de uso e ocupação da terra de cada classe ao longo dos anos e a análise do percentual de aumento ou diminuição de cada uma delas. Dessa forma, foi possível o entendimento da dinâmica temporal na área estudada e a verificação de quais ações antrópicas ocorreram na região (Sader et al., 1990; Singh, 1989).

Posteriormente, as imagens foram recortadas utilizando buffer de 100 metros (que corresponde à área prevista legalmente como APP do reservatório) (Figura 4) e buffer de 1000 metros a partir da margem da barragem (área usada para a classificação manual), em seguida foi analisada a evolução da cobertura e uso da terra nessas duas escalas de análise $(100 \mathrm{~m} \mathrm{e} 1000 \mathrm{~m})$ da mesma maneira que anteriormente, ou seja, foram consideradas as modificações ocorridas em cada classe estabelecida. 


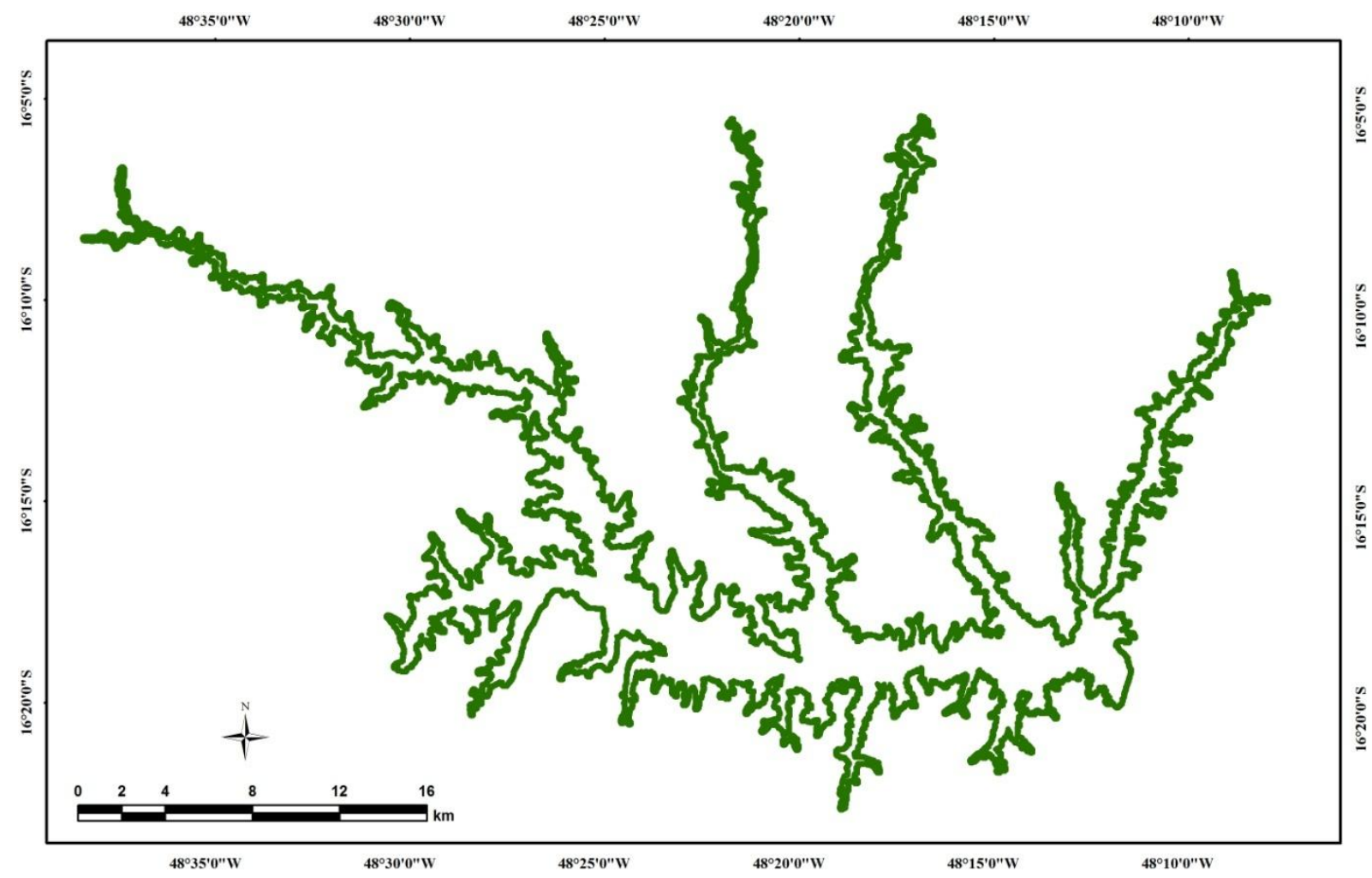

Figura 4: Área destinada à APP (buffer de100 metros a partir do reservatório). 


\section{RESULTADOS}

\subsection{Resultados da Análise Comparativa entre Métodos de Classificação Supervisionada}

\subsubsection{Resultado da classificação manual (imagem de referência)}

O resultado da classificação manual é mostrado na Figura 5. Observa-se que a classe de maior representatividade é a Pecuária, com mais de $41 \%$ da área ocupada no entorno de 1000 metros do reservatório (Tabela 3). A segunda classe de maior abrangência é o Cerradão (mais de 27\%), seguida de Cerrado (com mais de 18\%). A classe de Queimada possui a menor abrangência na área com $0,04 \%$. Nota-se que as classes: Pecuária, Cerradão e Cerrado ocupam quase que $90 \%$ de toda a área teste, sendo que quatro classes (Água, Pivô, Queimada e Reflorestamento) tem pouquíssima representatividade, uma vez que, somadas, não chegam a ocupar $1 \%$ da área.

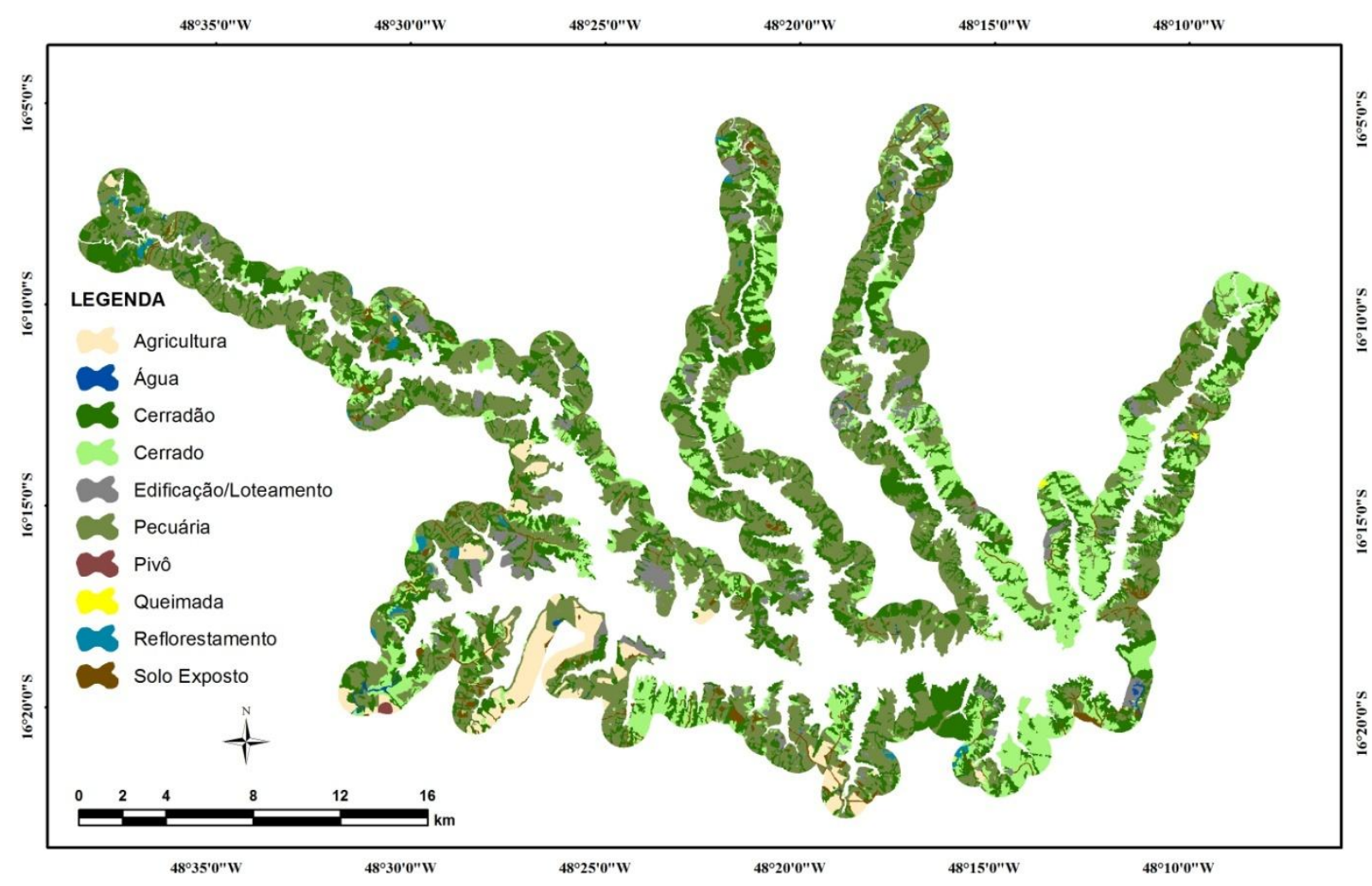

Figura 5: Classificação manual do uso e cobertura da terra na área de 1000 metros no entorno do reservatório. 
Observa-se que a classe Pecuária está distribuída em toda a área teste e que a classe Agricultura ocorre na parte sudoeste da área e que as classes Cerradão e Cerrado possuem uma ocorrência maior na porção leste (Figura 5).

Tabela 3: Cobertura e uso da terra na área teste (entorno do reservatório) em 2014.

\begin{tabular}{|c|c|c|}
\hline CLASSES & ÁREA (ha) & PORCENTAGEM \\
\hline Agricultura & 16.648 .251 & $3,73 \%$ \\
\hline Água & 1.769 .130 & $0,40 \%$ \\
\hline Cerradão & 123.110 .435 & $27,55 \%$ \\
\hline Cerrado & 83.710 .916 & $18,73 \%$ \\
\hline Edificação/Loteamento & 20.251 .414 & $4,53 \%$ \\
\hline Pecuária & 186.147.082 & $41,66 \%$ \\
\hline Pivô & 304.461 & $0,07 \%$ \\
\hline Queimada & 182.415 & $0,04 \%$ \\
\hline Reflorestamento & 2.395 .022 & $0,54 \%$ \\
\hline Solo Exposto & 12.309 .548 & $2,75 \%$ \\
\hline TOTAL & 446.828.678 & $100,00 \%$ \\
\hline
\end{tabular}

\subsubsection{Resultado da análise de acurácia}

A matriz de confusão relativa ao desempenho dos classificadores é mostrada na Tabela 4. Os classificadores de Mínima Distância e Paralelepípedo - DP3 apresentaram desempenhos razoáveis por causa dos valores menores que 0,4 do índice Kappa. Já os demais apresentaram resultados acima de 0,4, o que de acordo com os critérios de Landis e Koch (1977), são considerados bons.

Em relação à acurácia global tiveram melhor desempenho os classificadores Paralelepipedo - none (65,9\%), SAM - single value $(65,7 \%)$, SVM - linear (62,1\%) e SAM none $(61,9 \%)$. Os menores valores foram para os classificadores Mínima Distância - none (47,7\%) e Mínima Distância - DP3 (47,5\%).

Quanto ao índice Kappa os melhores resultados foram para os classificadores SAM single value (0,5366), SVM - linear (0,4975), SVM - polinomial $(0,4841)$ e Paralelepípedo none $(0,4841)$. E os piores resultados foram dos classificadores Mínima Distância - none (0,3547) e Mínima Distância - DP3 (0,342). 
Tabela 4: Acurácia e Índice Kappa (matriz de confusão a partir da classificação manual).

\begin{tabular}{|l|r|r|}
\hline Classificador & Acurácia & \multicolumn{1}{|c|}{ Kappa } \\
\hline Distância Mahalanobis & $59,42 \%$ & 0,4617 \\
\hline Máxima Verossimilhança & $53,79 \%$ & 0,4146 \\
\hline Mínima Distância - DP3 & $47,50 \%$ & 0,342 \\
\hline Mínima Distância - none & $47,70 \%$ & 0,3547 \\
\hline Paralelepípedo - none & $65,93 \%$ & 0,4841 \\
\hline Paralelepípedo - DP3 & $61,13 \%$ & 0,3795 \\
\hline SAM - none & $61,98 \%$ & 0,4831 \\
\hline SAM - single value & $65,67 \%$ & 0,5366 \\
\hline SID - none & $61,65 \%$ & 0,482 \\
\hline SID - single value & $61,81 \%$ & 0,4835 \\
\hline SVM - linear & $62,06 \%$ & 0,4975 \\
\hline SVM - sigmoidal & $58,47 \%$ & 0,4598 \\
\hline SVM - polinomial & $60,74 \%$ & 0,4841 \\
\hline SVM - radial & $60,66 \%$ & 0,4834 \\
\hline
\end{tabular}

Considerando os valores apresentados na Tabela 4, os classificadores que obtiveram melhores resultados de acurácia e índice Kappa foram: Paralelepípedo-none, SAM-single value, SAM-none, SVM-linear e SVM-polinomial.

Apesar dos classificadores SAM (single value) e Paralelepípedo (none) apresentarem uns dos melhores índices de acurácia global e Kappa (Tabela 4), estes tiveram um percentual de pixels não classificados de cerca de $40 \%$ para o SAM e $75 \%$ para o Paralelepípedo (none) de toda a área (Tabela 5).

Assim, entende-se que o SVM (linear) foi o classificador que obteve o melhor resultado entre as classificações realizadas (segundo colocado em relação ao índice Kappa e terceiro na acurácia global), após a eliminação das classificações SAM (single value) e Paralelepípedo (none). Em seguida, o SVM (polinomial) foi o classificador que obteve o segundo melhor resultado no índice Kappa e o SAM (none) foi o que obteve o segundo melhor valor na acurácia global.

$\mathrm{Na}$ análise da matriz de confusão Imagem X Imagem do classificador SVM (linear) nota-se que as classes Pivô, Cerradão e Cerrado obtiveram os maiores valores de acerto $(80,58 \%, 79,82 \%$ e $71,03 \%$, respectivamente - Tabela 6$)$. O percentual de acerto mais baixo foi o da classe Solo Exposto (1,91\%). Agricultura, Água e Queimada apresentaram erros 
elevados de comissão $(79,31 \%, 81,18$ e 96,72\%, respectivamente), uma vez que o classificador superestimou o número de pixels como pertencentes a essas classes (Tabela 7).

Tabela 5: Percentual de pixels classificados na comparação da matriz de confusão Imagem X Imagem de cada classificador.

\begin{tabular}{|l|c|c|r|}
\hline Classificadores & Pixel classificados & Pixels não classificados & Total \\
\hline Mahalanobis & 99,83 & 0,17 & 100 \\
\hline Máxima Verossimilhança & 99,83 & 0,17 & 100 \\
\hline Mínima Distância (DP3) & 47,58 & 52,42 & 100 \\
\hline Mínima Distância (none) & 99,83 & 0,17 & 100 \\
\hline Paralelepípedo (none) & 25,74 & 74,26 & 100 \\
\hline Paralelepípedo (DP3) & 96,04 & 3,96 & 100 \\
\hline SAM (none) & 99,83 & 0,17 & 100 \\
\hline SAM (SV) & 62,64 & 37,36 & 100 \\
\hline SID (none) & 99,83 & 0,17 & 100 \\
\hline SID (SV) & 99,40 & 0,60 & 100 \\
\hline SVM (linear) & 99,83 & 0,17 & 100 \\
\hline SVM (sigmoidal) & 99,83 & 0,17 & 100 \\
\hline SVM (polinomial) & 99,83 & 0,17 & 100 \\
\hline SVM (radial) & 99,83 & 0,17 & 100 \\
\hline
\end{tabular}

Tabela 6: Matriz de confusão do classificador SVM (linear).

\begin{tabular}{|l|r|r|r|r|r|r|r|r|r|r|r|}
\hline \multicolumn{1}{|l}{} & $\mathbf{2}$ & $\mathbf{3}$ & $\mathbf{4}$ & $\mathbf{5}$ & $\mathbf{6}$ & $\mathbf{7}$ & $\mathbf{8}$ & $\mathbf{9}$ & $\mathbf{1 0}$ & $\mathbf{1 4}$ \\
\hline $\mathbf{1}$ & 58,93 & 0,74 & 2,75 & 5,20 & 8,89 & 13,36 & 8,41 & 10,33 & 7,87 & 12,00 & 10,35 \\
\hline $\mathbf{2}$ & 0,09 & 42,29 & 0,89 & 0,64 & 0,46 & 0,59 & 0,00 & 0,47 & 0,00 & 0,25 & 0,79 \\
\hline $\mathbf{3}$ & 0,26 & 12,58 & 79,82 & 10,94 & 2,30 & 3,28 & 0,00 & 1,41 & 39,61 & 1,06 & 24,92 \\
\hline $\mathbf{4}$ & 1,42 & 18,44 & 13,92 & 71,03 & 10,73 & 20,05 & 0,00 & 25,35 & 6,82 & 8,08 & 26,51 \\
\hline $\mathbf{5}$ & 8,54 & 7,51 & 0,49 & 2,03 & 46,46 & 8,35 & 0,00 & 12,21 & 0,83 & 36,26 & 7,62 \\
\hline $\mathbf{6}$ & 29,80 & 3,36 & 1,70 & 9,48 & 29,62 & 53,40 & 0,00 & 3,76 & 1,16 & 38,60 & 28,57 \\
\hline $\mathbf{7}$ & 0,34 & 0,34 & 0,00 & 0,00 & 0,00 & 0,00 & 80,58 & 0,00 & 0,29 & 0,00 & 0,07 \\
\hline $\mathbf{8}$ & 0,15 & 14,06 & 0,14 & 0,50 & 1,07 & 0,70 & 0,00 & 46,48 & 0,00 & 1,71 & 0,60 \\
\hline $\mathbf{9}$ & 0,10 & 0,68 & 0,09 & 0,01 & 0,02 & 0,02 & 11,01 & 0,00 & 43,31 & 0,01 & 0,29 \\
\hline $\mathbf{1 0}$ & 0,25 & 0,00 & 0,00 & 0,00 & 0,38 & 0,08 & 0,00 & 0,00 & 0,00 & 1,91 & 0,12 \\
\hline $\mathbf{1 1}$ & $\mathbf{9 9 , 8 8}$ & $\mathbf{1 0 0 , 0 0}$ & $\mathbf{9 9 , 8 0}$ & $\mathbf{9 9 , 8 3}$ & $\mathbf{9 9 , 9 2}$ & $\mathbf{9 9 , 8 4}$ & $\mathbf{1 0 0 , 0 0}$ & $\mathbf{1 0 0 , 0 0}$ & $\mathbf{9 9 , 8 9}$ & $\mathbf{9 9 , 8 8}$ & $\mathbf{9 9 , 8 3}$ \\
\hline $\mathbf{1 2}$ & $\mathbf{0 , 1 2}$ & $\mathbf{0 , 0 0}$ & $\mathbf{0 , 2 0}$ & $\mathbf{0 , 1 7}$ & $\mathbf{0 , 0 8}$ & $\mathbf{0 , 1 6}$ & $\mathbf{0 , 0 0}$ & $\mathbf{0 , 0 0}$ & $\mathbf{0 , 1 1}$ & $\mathbf{0 , 1 2}$ & $\mathbf{0 , 1 7}$ \\
\hline $\mathbf{1 3}$ & 100,00 & 100,00 & 100,00 & 100,00 & 100,00 & 100,00 & 100,00 & 100,00 & 100,00 & 100,00 & 100,00 \\
\hline
\end{tabular}

Legenda: Agricultura (1), Água (2), Cerradão (3), Cerrado (4), Edificações e Loteamentos (5), Pecuária (6), Pivô (7), Queimada (8), Reflorestamento (9), Solo Exposto (10), Total de pixels classificados (11), Pixels não classificados (12), Total de pixels (13), Total (14). 
Tabela 7: Erros de comissão e omissão da classificação SVM (linear).

\begin{tabular}{|l|l|l|}
\hline Classe & Comissão (\%) & Omissão (\%) \\
\hline Agricultura & 79.31 & 41.00 \\
\hline Água & 81.18 & 57.71 \\
\hline Cerradão & 15.54 & 20.02 \\
\hline Cerrado & 49.42 & 28.85 \\
\hline Edificação/Loteamento & 72.17 & 53.50 \\
\hline Pecuária & 20.45 & 46.52 \\
\hline Pivô & 22.78 & 19.42 \\
\hline Queimada & 96.72 & 53.52 \\
\hline Reflorestamento & 17.14 & 56.64 \\
\hline Solo Exposto & 51.20 & 98.09 \\
\hline
\end{tabular}

O classificador SVM (polinomial) apresentou índice de acerto elevado para as classes Cerradão e Cerrado $(80,14 \%$ e $70,24 \%)$ e baixo índice para Solo Exposto $(2,48 \%)$ (Tabela 8 ). Agricultura, Água, Edificações e Loteamentos e Queimadas apresentaram elevado erro de comissão $(84,63 \%, 81,52 \%, 70,65 \%$ e 97,27\%), enquanto Solo Exposto apresentou elevado erro de omissão $(97,52 \%)$.

Tabela 8: Matriz de confusão do classificador SVM (polinomial).

\begin{tabular}{|l|r|r|r|r|r|r|r|r|r|r|r|r|}
\hline \multicolumn{1}{|r|}{} & $\mathbf{2}$ & $\mathbf{3}$ & $\mathbf{4}$ & $\mathbf{5}$ & $\mathbf{6}$ & $\mathbf{7}$ & $\mathbf{8}$ & $\mathbf{9}$ & \multicolumn{1}{l|}{} & $\mathbf{1 4}$ \\
\hline $\mathbf{1}$ & 53,58 & 1,02 & 3,82 & 9,75 & 11,07 & 16,33 & 8,41 & 10,80 & 8,05 & 11,90 & 12,67 \\
\hline $\mathbf{2}$ & 0,09 & 42,74 & 0,91 & 0,67 & 0,46 & 0,62 & 0,00 & 0,47 & 0,00 & 0,25 & 0,81 \\
\hline $\mathbf{3}$ & 0,26 & 14,00 & 80,14 & 11,16 & 2,38 & 3,39 & 0,00 & 1,41 & 40,19 & 1,12 & 25,10 \\
\hline $\mathbf{4}$ & 1,35 & 15,88 & 12,66 & 70,24 & 11,99 & 20,04 & 0,00 & 22,54 & 6,38 & 9,22 & 26,10 \\
\hline $\mathbf{5}$ & 7,74 & 5,98 & 0,29 & 1,48 & 43,08 & 7,17 & 0,00 & 8,92 & 0,33 & 34,12 & 6,70 \\
\hline $\mathbf{6}$ & 35,37 & 3,02 & 1,67 & 5,66 & 29,18 & 51,23 & 0,00 & 4,23 & 1,60 & 38,82 & 27,11 \\
\hline $\mathbf{7}$ & 0,32 & 0,00 & 0,00 & 0,00 & 0,00 & 0,00 & 74,20 & 0,00 & 0,44 & 0,00 & 0,07 \\
\hline $\mathbf{8}$ & 0,18 & 16,39 & 0,22 & 0,85 & 1,26 & 0,91 & 0,00 & 51,64 & 0,00 & 1,95 & 0,81 \\
\hline $\mathbf{9}$ & 0,10 & 0,97 & 0,09 & 0,01 & 0,02 & 0,02 & 17,39 & 0,00 & 42,91 & 0,01 & 0,29 \\
\hline $\mathbf{1 0}$ & 0,88 & 0,00 & 0,00 & 0,00 & 0,49 & 0,12 & 0,00 & 0,00 & 0,00 & 2,48 & 0,18 \\
\hline $\mathbf{1 1}$ & $\mathbf{9 9 , 8 8}$ & $\mathbf{1 0 0 , 0 0}$ & $\mathbf{9 9 , 8 0}$ & $\mathbf{9 9 , 8 3}$ & $\mathbf{9 9 , 9 2}$ & $\mathbf{9 9 , 8 4}$ & $\mathbf{1 0 0 , 0 0}$ & $\mathbf{1 0 0 , 0 0}$ & $\mathbf{9 9 , 8 9}$ & $\mathbf{9 9 , 8 8}$ & $\mathbf{9 9 , 8 3}$ \\
\hline $\mathbf{1 2}$ & $\mathbf{0 , 1 2}$ & $\mathbf{0 , 0 0}$ & $\mathbf{0 , 2 0}$ & $\mathbf{0 , 1 7}$ & $\mathbf{0 , 0 8}$ & $\mathbf{0 , 1 6}$ & $\mathbf{0 , 0 0}$ & $\mathbf{0 , 0 0}$ & $\mathbf{0 , 1 1}$ & $\mathbf{0 , 1 2}$ & $\mathbf{0 , 1 7}$ \\
\hline $\mathbf{1 3}$ & 100,00 & 100,00 & 100,00 & 100,00 & 100,00 & 100,00 & 100,00 & 100,00 & 100,00 & 100,00 & 100,00 \\
\hline
\end{tabular}

Legenda: Agricultura (1), Água (2), Cerradão (3), Cerrado (4), Edificações e Loteamentos (5), Pecuária (6), Pivô (7), Queimada (8), Reflorestamento (9), Solo Exposto (10), Total de pixels classificados (11), Pixels não classificados (12), Total de pixels (13), Total (14).

O classificador SAM (none), embora tenha apresentado a quarta melhor acurácia global, apresentou boa acurácia apenas para duas classes, Cerradão e Pivô (86,33\% e 75,94\%) 
(Tabela 10). A acurácia de Edificação e Loteamento se destacou com relação aos demais classificadores $(22,10 \%)$, o que pode ter contribuído para o aumento da acurácia global.

Dentro desse contexto, o classificador SVM (linear) foi considerado a melhor opção para aplicação na área de estudo. Contudo, a partir da observação das classes que apresentaram erro (de comissão e omissão) e considerando o objetivo do trabalho de fazer a distinção entre as áreas de vegetação preservada do entorno do reservatório, das demais ocupações, foi feito novo agrupamento das classes de cobertura e uso da terra. As classes agricultura, pivô, pecuária, solo exposto e edificações e loteamento foram reunidas em uma única classe denominada Agropecuária. A classe Cerradão agrupou as classes cerradão e reflorestamento, enquanto que as outras classes foram mantidas (água, queimada e cerrado).

Após o reagrupamento das classes foi feita uma nova análise da classificação SVM (linear). Nesta nova classificação realizada com o reagrupamento das classes, o resultado foi superior aos anteriormente encontrado, e todos os elementos da matriz de confusão. A acurácia passou a ser de 77,3\%, enquanto que o índice Kappa passou a ter uma classificação considerada por Dorais e Cardille (2011) como muito boa $(0,6365)$.

Tabela 10: Matriz de confusão do classificador SAM (none).

\begin{tabular}{|c|c|c|c|c|c|c|c|c|c|c|c|}
\hline & 1 & 2 & 3 & 4 & 5 & 6 & 7 & 8 & 9 & 10 & 14 \\
\hline 1 & 35,35 & 1,25 & 0,08 & 4,77 & 7,53 & 11,69 & 0,00 & 7,98 & 0,07 & 16,80 & 8,03 \\
\hline 2 & 0,01 & 15,31 & 0,03 & 0,04 & 0,10 & 0,07 & 0,00 & 0,00 & 0,00 & 0,03 & 0,10 \\
\hline 3 & 2,69 & 23,11 & 86,33 & 16,38 & 4,27 & 6,43 & 8,99 & 2,82 & 42,80 & 1,85 & 29,26 \\
\hline 4 & 3,20 & 3,93 & 9,39 & 62,13 & 7,41 & 18,92 & 0,00 & 15,49 & 4,61 & 5,60 & 22,92 \\
\hline 5 & 2,09 & 34,55 & 0,36 & 1,08 & 24,99 & 4,46 & 0,00 & 2,35 & 0,07 & 17,79 & 4,07 \\
\hline 6 & 47,54 & 17,87 & 3,46 & 15,24 & 41,38 & 56,23 & 5,22 & 20,66 & 3,81 & 33,84 & 32,45 \\
\hline 7 & 0,00 & 0,17 & 0,00 & 0,00 & 0,00 & 0,00 & 75,94 & 0,00 & 4,17 & 0,00 & 0,08 \\
\hline 8 & 0,73 & 0,40 & 0,00 & 0,01 & 1,34 & 0,28 & 0,00 & 44,13 & 0,00 & 1,87 & 0,29 \\
\hline 9 & 0,02 & 0,97 & 0,15 & 0,02 & 0,02 & 0,01 & 9,86 & 0,00 & 44,36 & 0,00 & 0,30 \\
\hline 10 & 8,25 & 2,45 & 0,01 & 0,16 & 12,89 & 1,75 & 0,00 & 6,57 & 0,00 & 22,10 & 2,33 \\
\hline 11 & 99,88 & 100,00 & 99,80 & 99,83 & 99,92 & 99,84 & 100,00 & 100,00 & 99,89 & 99,88 & 99,83 \\
\hline 12 & 0,12 & 0,00 & 0,20 & $\mathbf{0 , 1 7}$ & 0,08 & 0,16 & 0,00 & $\mathbf{0 , 0 0}$ & 0,11 & 0,12 & 0,17 \\
\hline 13 & 100,00 & 100,00 & 100,00 & 100,00 & 100,00 & 100,00 & 100,00 & 100,00 & 100,00 & 100,00 & 100,00 \\
\hline
\end{tabular}

Após o reagrupamento das classes o desempenho do classificador SVM foi aprimorado. A matriz de confusão demonstra um bom desempenho para Agropecuária 
$(83,17 \%)$, Cerradão $(75,76 \%)$, e Cerrado $(65,34 \%)$ e, um menor desempenho para as classes de Queimada (45,87\%) e Água (18,13\%) na classificação do SVM (linear) (Tabela 11).

Tabela 11: Matriz de confusão da classificação SVM (linear, após reagrupamento de classes).

\begin{tabular}{|l|l|l|l|l|l|l|}
\hline Classes & Agropecuária & Água & Cerradão & Cerrado & Queimada & Total \\
\hline Agropecuária & 83,17 & 17,88 & 9,91 & 23,03 & 30,73 & 50,04 \\
\hline Água & 0,19 & 18,13 & 0,14 & 0,11 & 0 & 0,23 \\
\hline Cerradão & 1,79 & 15,34 & 75,76 & 10,71 & 1,83 & 24,89 \\
\hline Cerrado & 13,78 & 19,11 & 13,85 & 65,34 & 21,56 & 23,89 \\
\hline Queimada & 1,07 & 29,54 & 0,33 & 0,82 & 45,87 & 0,95 \\
\hline Total & 100 & 100 & 100 & 100 & 100 & 100 \\
\hline
\end{tabular}

Destaca-se o número elevado $(97,88 \%)$ de erro de comissão para queimada, devido à elevada quantidade de pixels de outras classes que foram classificados como queimada. E elevado erro de omissão para água, ou seja, pixels correspondentes à água classificados como pertencentes a outras classes (Tabela 12). Isto provavelmente é resultante dos inúmeros pequenos reservatórios de água para dessedentação animal, que foram classificados manualmente na classe Água. Contudo, nota-se que devido ao reduzido tamanho, baixa profundidade, ou turbidez da água, esses pixels receberam outras classificações. Observou-se também que diversos pixels ao longo de toda a margem do reservatório foram classificados como queimada e não como água, o que contribuiu para o aumento dos valores de erro de comissão e omissão, respectivamente, para estas classes (Figura 6).

Tabela 12: Erros de comissão e omissão.

\begin{tabular}{|l|l|l|}
\hline \multicolumn{1}{|c|}{ Classes } & $\begin{array}{c}\text { Comissão } \\
(\%)\end{array}$ & $\begin{array}{c}\text { Omissão } \\
(\%)\end{array}$ \\
\hline Agropecuária & 14,86 & 16,83 \\
\hline Água & 67,97 & 81,87 \\
\hline Cerradão & 12,35 & 24,24 \\
\hline Cerrado & 46,61 & 34,66 \\
\hline Queimada & 97,88 & 54,13 \\
\hline
\end{tabular}

A Figura 6 apresenta um recorte da imagem Landsat 2014 e das classificações realizadas, onde é possível visualizar erros de comissão de pixels correspondente à água, erroneamente classificados como queimadas. Nota-se a semelhança entre a classificação manual (B) e a classificação supervisionada SVM-linear. 
A

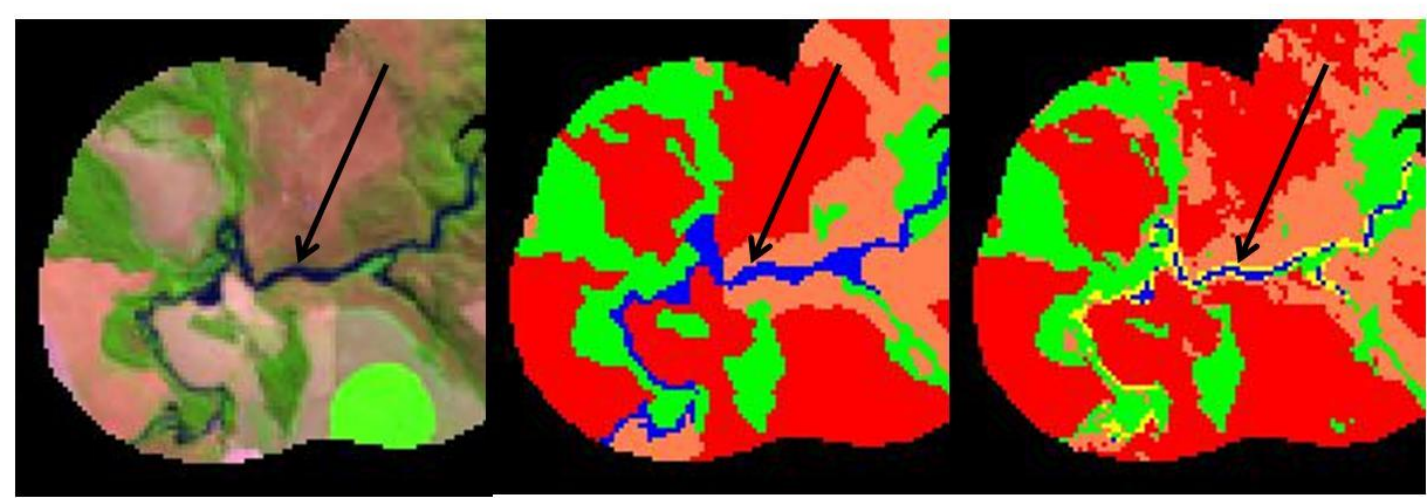

Figura 6 - (A) Recorte da Imagem Landsat de 2014 (composição R: banda 6, G: banda 5, B: banda 4); (B) Classificação manual; (C) Classificação supervisionada SVM-linear. Em que: azul = água, verde = cerradão, bege $=$ cerrado, vermelho $=$ agropecuária e amarelo $=$ queimada .

\subsection{Resultados da Análise Multitemporal}

$\mathrm{Na}$ análise da evolução temporal do uso e cobertura da terra, considerando a área total dos oito municípios (Figura 7 e 8), verifica-se um aumento da área ocupada por agropecuária chegando a quase $70 \%$ da área em 2015. No entanto, entre 2008 e 2010 ocorreu um decréscimo de área ocupada; em 2008, a área era de 65\% e em 2010 caiu para 62\%. Infere-se que isto ocorreu por que áreas antes consideradas como Agropecuária se transformaram em áreas de reflorestamento, que foram incluídas da classe Cerradão, conforme mostra a Figura 9 .

A classe Água também obteve aumento constante, em decorrência dos pequenos reservatórios artificiais criados, associados ao aumento da pecuária, passando de $0,13 \%$ para 2,18\% da área total entre 1988 e 2015. A classe de Cerrado, que em 1988 representava 21\% da área total, chegou a 14\% em 2014 e 9\% em 2015, o que representa um decréscimo de mais de $50 \%$ de sua área, ou seja, mais da metade da área antes ocupada por vegetação natural agora está antropizada. Já a classe Queimada variou pouco ao longo dos anos, sempre na casa do $1 \%$. Em 2015, esta classe representava 0,5\% da área. 

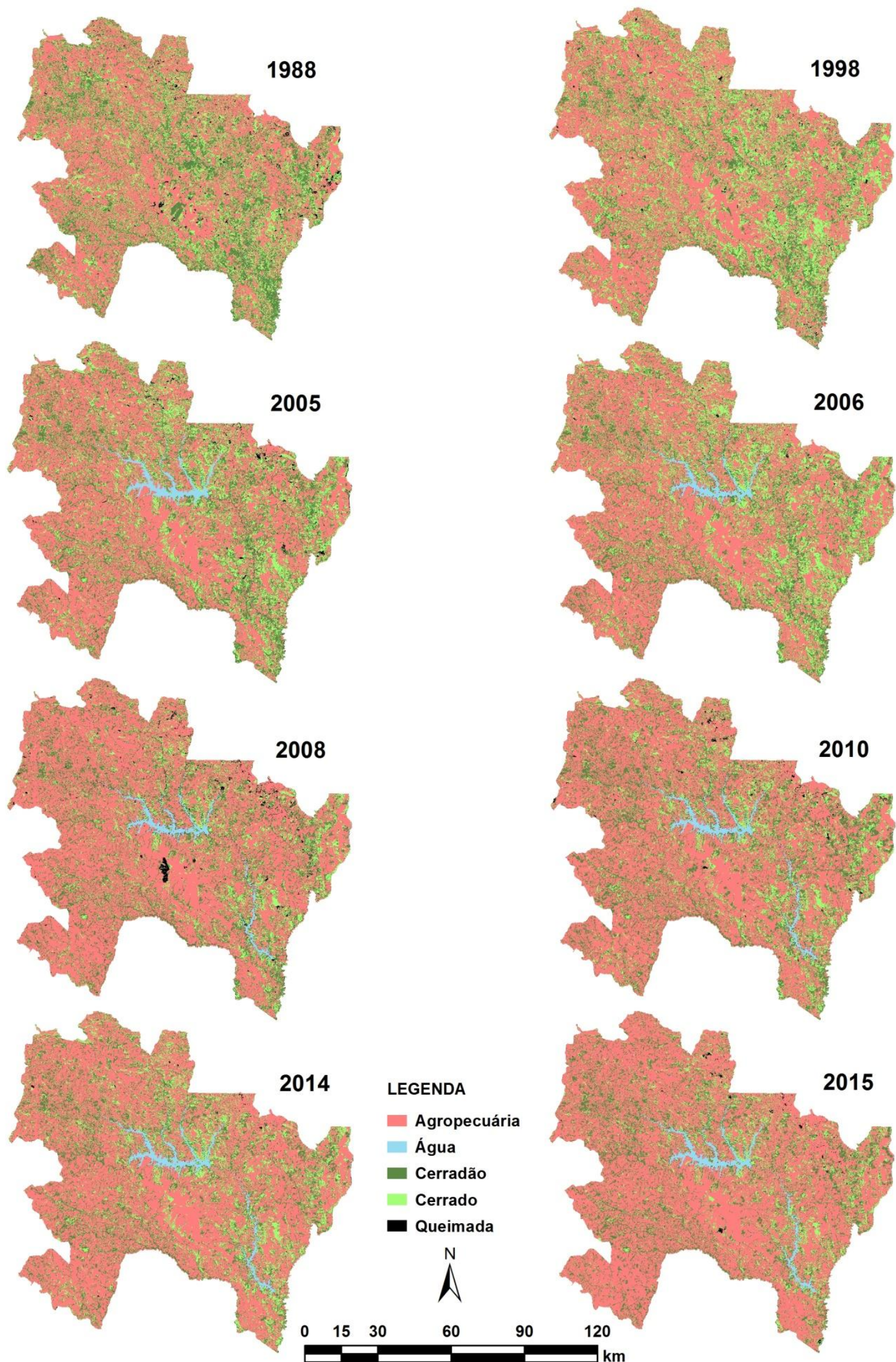

Figura 7: Classificação temporal do uso e cobertura da terra para os oito municípios analisados. 


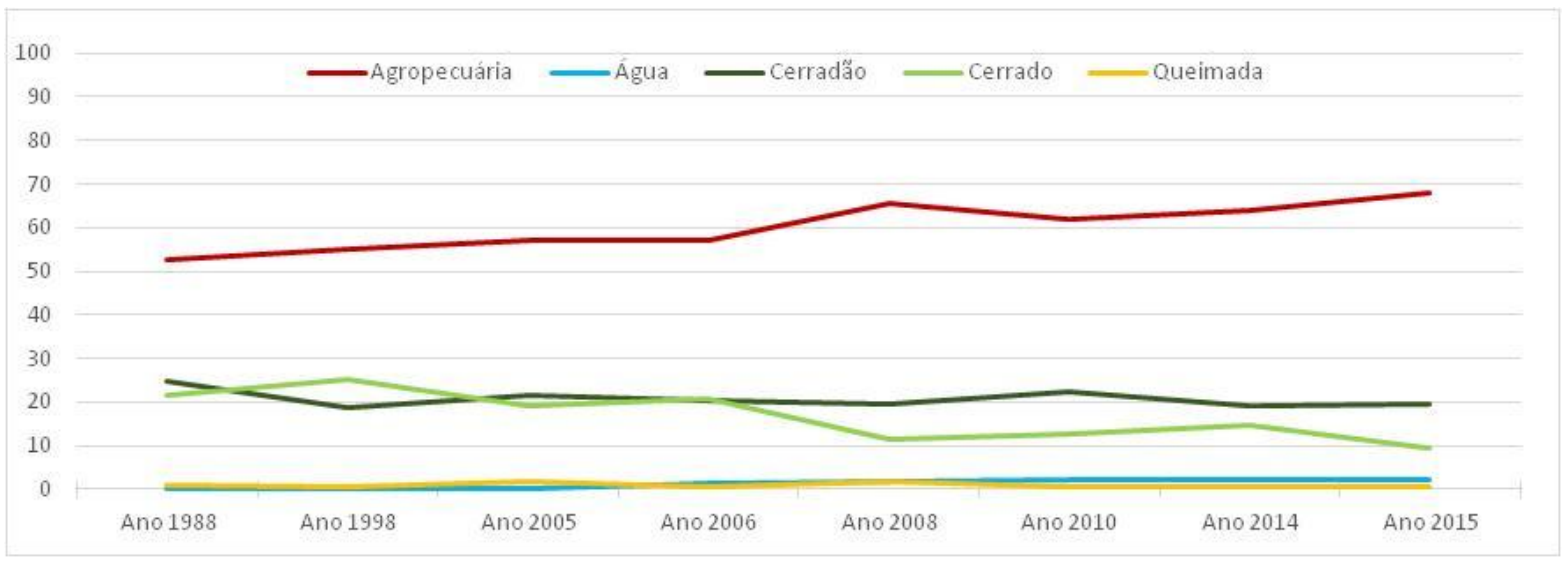

Figura 8: Evolução percentual do uso e cobertura da terra para os oito municípios analisados.
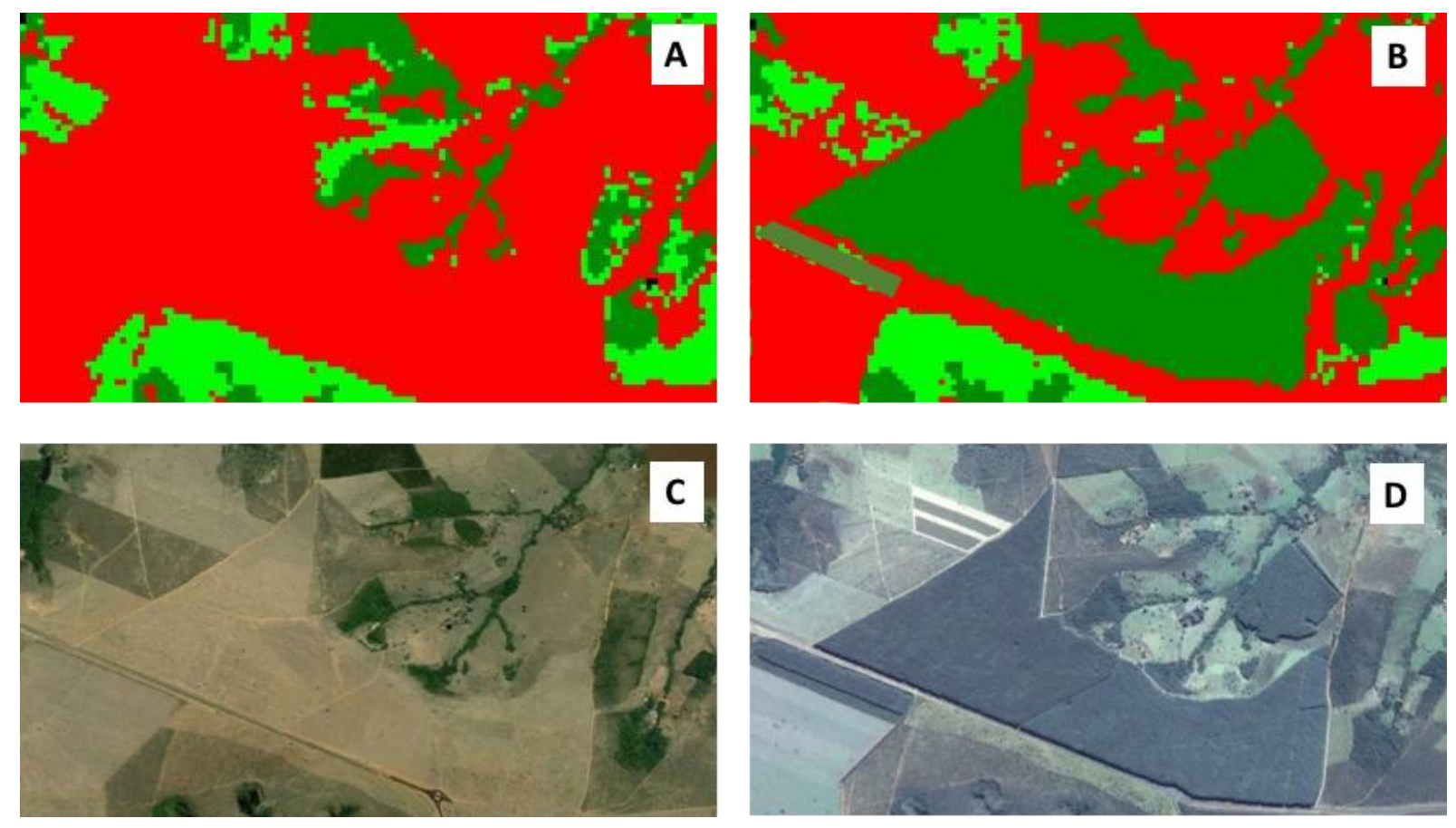

Figura 9: Exemplo de área modificada de Agropecuária para Cerradão (Reflorestamento). (A) Classificação na imagem de 2006; (B) Classificação da imagem de 2010; (C) Imagem do Google Earth de 2006; (D) Imagem do Google Earth de 2010.

$\mathrm{Na}$ análise da evolução temporal no buffer de 1000 metros verifica-se que o comportamento das classes é parecido com o da área total dos municípios (Figura 10). A classe agropecuária corresponde ao maior percentual e sofreu aumento, embora não constante, entre os anos de 1988 até 2015, passando de aproximadamente 40\% do total da área para 60\% no último ano de análise. Destaca-se o decréscimo ocorrido em 2010 e 2014, seguido de novo aumento em 2015. 
Nota-se também que as classes de Cerradão e Cerrado estão mais próximas, ou seja, possuem um comportamento mais parecido no percentual de uso e ocupação da terra. Dos $450,532 \mathrm{~km}^{2}$ de área do buffer estabelecido no entorno da barragem (excluída para todos os anos a área ocupada pelo espelho d'água da barragem), 41\% eram ocupados por Agropecuária em 1988, chegando a 55\% em 2015. A classe Água oscilou bastante durante o período analisado, passando de 0,07\% em 1988 para 0,72\%, em 2015. A classe Cerradão representou $32,29 \%$ da área total em 1988, chegando a 27\% em 2005 e, permaneceu perto deste valor até 2015 em que teve $25 \%$ de área ocupada. O Cerrado que ocupava 25\% da área total em 1988, vem apresentando um decaimento contínuo ao longo dos anos, chegando a $17 \%$ de área ocupada em 2015. Já a área queimada teve pouca variação na área analisada.

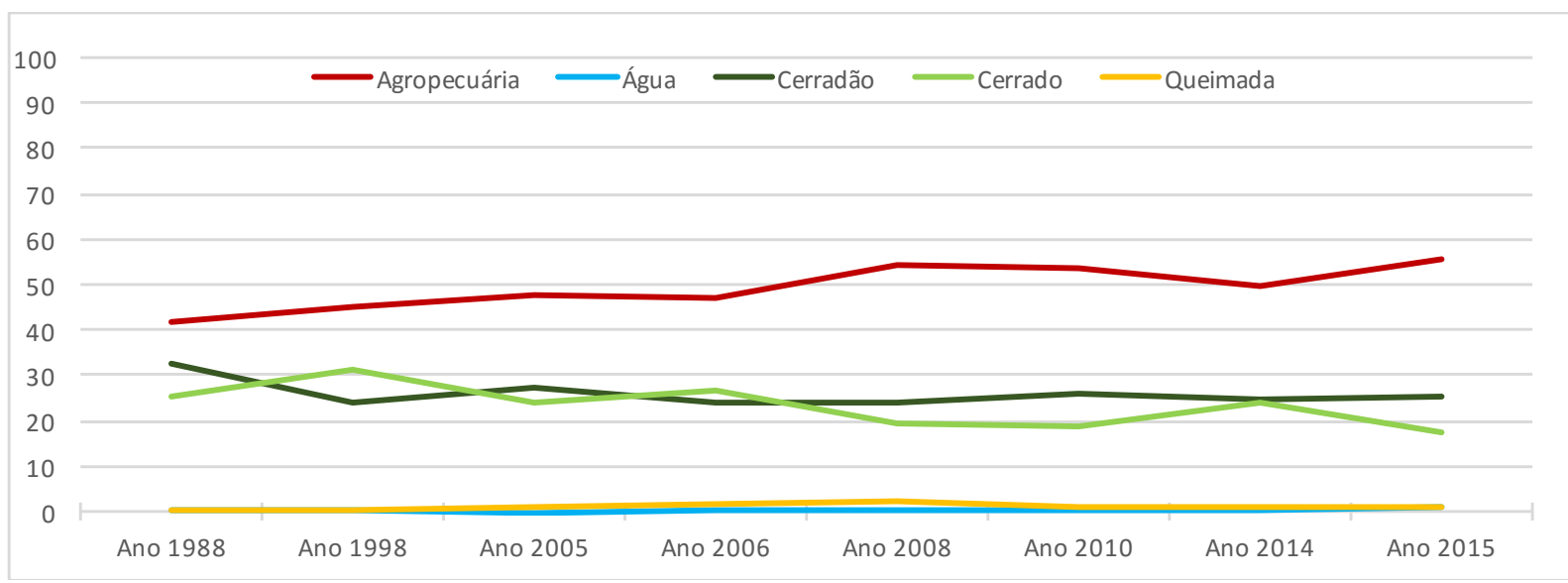

Figura 10: Evolução do uso e ocupação da terra para a área do buffer de 1000 metros ao longo da barragem.

$\mathrm{Na}$ análise da área do buffer de 100 metros (total de 77,78 km²), destinada às APPs no entorno do reservatório, percebe-se uma mudança no comportamento das classes (Figura 11). Em 1988 as classes de Agropecuária e Cerradão praticamente tinham o mesmo percentual de uso e cobertura da terra. Agropecuária tinha 36\% e o Cerradão tinha $41 \%$ de área ocupada. No entanto, já em 1998 este comportamento se inverte, uma vez que a classe Agropecuária passa a ter cerca de $40 \%$ e o Cerradão, 32\%. Este comportamento permanece até os anos de 2010, ou seja, a classe Agropecuária sempre tendo um percentual de ocupação maior do que a classe Cerradão. No entanto, a partir de 2014 este comportamento muda novamente e as classes começam a ter um percentual parecido, em torno de $35 \%$ de área ocupada.

A classe Queimada chama também a atenção e por possuir um comportamento diferenciado das análises anteriores. Esta classe, nos anos de 2006 e 2008, chegou a ter quase 
que $10 \%$ de área ocupada na APP do reservatório. Este percentual decaiu nos anos seguintes chegando a cerca de 5\% em 2015, o valor elevado é atribuído, como mencionado anteriormente, às áreas próximas a margem de rios e da barragem classificados erroneamente com queimadas no lugar de água.

Outra classe que chama a atenção é a classe Água. Esta classe teve um aumento de cerca de $400 \%$ nos anos analisados, pois tinha 0,1\% em 1988 e foi para cerca de $4 \%$ em 2015, justificado pelo aumento de pequenos reservatórios, conforme identificado na classificação manual, e ao aumento do volume dos rios após o enchimento do reservatório.

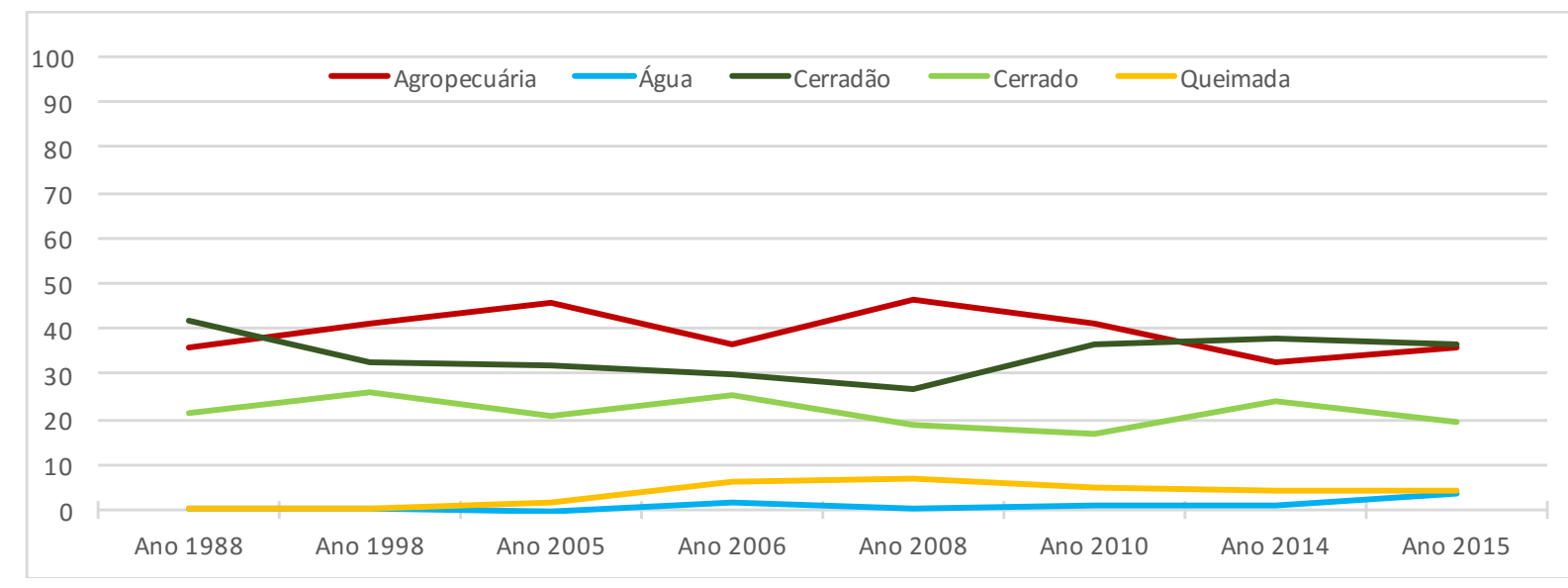

Figura 11: Evolução do uso e cobertura da terra para a área de APP de 100 metros no entorno do reservatório.

Somando os percentuais de Cerradão e Cerrado, a faixa de 100 metros a partir da margem do reservatório apresenta 56,12\% de sua área coberta por vegetação. 


\section{DISCUSSÃO}

A primeira etapa desta pesquisa, que correspondeu ao mapeamento manual do buffer de 1000 metros a partir da margem do reservatório com o auxílio de imagens de alta resolução (RapidEye e Google Earth), possibilitou o conhecimento inicial do estado do uso e cobertura da terra na área de estudo. As imagens de alta resolução permitiram a identificação de usos, que na imagem Landsat não estavam adequadamente definidos.

O teste com os classificadores supervisionados possibilitou a seleção do classificador SVM uma vez que este demonstrou desempenho superior aos demais, com bons valores para o índice Kappa e para acurácia global, sendo, portanto, considerado adequado para realização do mapeamento de uso e cobertura da terra na área de estudo. Conforme já descrito por Mountrakis et al. (2011), o SVM tem sido amplamente usado devido à sua superioridade sobre os demais e por apresentar capacidade de boa generalização mesmo com limitado número de amostras.

O teste realizado obteve resultado semelhante a outros estudos (Niknejad et al., 2014; Pal e Mather, 2005; Yousefi et al., 2015) que igualmente compararam classificadores de imagens de satélite visando a realização de mapeamento de uso e cobertura da terra e que identificaram o classificador SVM como aquele de melhor desempenho e com melhores resultado de índice Kappa e da acurácia global. No entanto, a comparação de dados com outros estudos é limitada uma vez que as pesquisas encontradas não usaram a mesma metodologia e os grupos de classificadores testados foram diferentes.

Pal e Mather (2005), por exemplo, realizaram comparação entre o SVM, máxima verossimilhança e rede neural, usando imagens Landsat ETM+ e DAIS, em áreas no leste da Inglaterra e no centro da Espanha e concluíram que o SVM pode alcançar os melhores resultados mesmo que o tamanho da amostra de treinamento seja pequeno. Os autores fizeram testes com os tipos kernel disponíveis e obtiveram melhor resultado para o radial, diferente do teste da presente pesquisa que identificou o tipo kernel linear como o de melhor desempenho. Obtiveram como melhor resultado para o SVM 87,9\% de acurácia e 0,87 de índice Kappa; para o máxima verossimilhança $82,9 \%$ e 0,80 e; para rede neural $85,1 \%$ e 0,83 .

Outra questão diz respeito ao número de classes estabelecidas. Niknejad et al. (2014), por exemplo, compararam os classificadores MaxVer, mínima distância, paralelepípedo, distância mahalanobis, SAM, SID, binary encoding e SVM para uma área da floresta de 
Zagros no Irã, usando imagens Landsat ETM+, e estabeleceram apenas duas classes: Floresta e Não-floresta. Concluíram que o SVM foi o mais acurado dentre todos, com 0,7069 de índice Kappa e 88,65\% de acurácia global, ficando como segundo melhor classificador o MaxVer com 0,6262 de Kappa e 84,08\% de acurácia. Os autores destacaram a rapidez computacional do SVM e a capacidade de obter melhores resultados usando poucas amostras de treinamento. Dessa maneira, entende-se que o presente trabalho poderia se beneficiar com o reagrupamento de classes no intuito de reduzir o seu número sem comprometer os objetivos da pesquisa, contudo, a realização de testes seria necessária.

Resultados semelhantes também foram encontrados quando usadas imagens de outros satélites. Deilmai et al. (2014) compararam os classificadores SVM e MaxVer para a região de Johor na Malásia (usando imagem ASTER), e obteve para este último os melhores resultados para índice Kappa $(0,86)$ e para acurácia global $(91,67 \%)$, contra 0,65 e 78,33\% do primeiro. O estudo observou que o SVM obteve desempenho superior, sobretudo em áreas complexas com a mistura de pixels. Manabe e Rocha (2013) compararam os classificadores Max Ver, árvore de decisão, SVM e redes neurais usando imagens MODIS/NDVI para região agrícola do estado de Mato Grosso. Obteve valores próximos para todos os classificadores, com pequena superioridade do SVM (acurácia geral de 0,93 e índice Kappa de 0,829); os demais obtiveram acurácia geral de 0,927 (MaxVer), 0,917 (árvore de decisão), 0,927 (redes neurais) e índice Kappa de 0,824 (MaxVer), 0,805 (árvore de decisão) e 0,825 (redes neurais).

O uso do sensoriamento remoto como ferramenta para identificar o uso e cobertura da terra, conforme realizado na presente pesquisa, mostrou ser eficiente para identificar as modificações ocorridas ao longo do tempo - assim como em Costa et al. (1996) e Vasconcelos e Novo (2004) - apresentou boa acurácia e foi feito de maneira rápida.

A análise multitemporal de imagens de satélites demonstrou ser de fundamental importância para a compreensão e quantificação das modificações espaciais ocorridas (Rawat e Kumar, 2015), sendo uma ferramenta eficiente e economicamente viável para subsidiar o gerenciamento da terra e a tomada de decisão (Yuan et al., 2005).

No mapeamento dos oito municípios da área de estudo foi verificada a predominância da classe Agropecuária, que aumentou de 52,45\% em 1988 para 68,06\% em 2015, conforme tendência de crescimento demonstrada em outros estudos que também avaliaram as mudanças de uso e cobertura da terra em municípios brasileiros (Castro et al., 2013; Pinheiro et al., 2015; Spagnolo et al., 2012). 
$\mathrm{Na}$ área recortada de 100 metros a partir da margem do reservatório, foi observado que. para o último ano (2015), a vegetação natural (cerrado e cerradão) correspondia a $56,12 \%$ da área, o que faz com que as APPs estejam abaixo do percentual demandado pela legislação brasileira. Para reverter o quadro de não atendimento da legislação ambiental é necessária a implantação, por parte das empresas responsáveis pelas usinas hidrelétricas, de programas socioambientais que assegurem a recuperação dos meios atingidos, como no exemplo da usina hidrelétrica de Itaipu, cujo programa Cultivando Água Boa foi considerado pela ONU como referência mundial na gestão de recursos hídricos (ONU, 2015). O projeto tem como objetivo a preservação da vegetação dos afluentes do lago de Itaipu e contribui significativamente para a conservação das APPs do seu reservatório (Chaves et al., 2012). 


\section{CONCLUSÕES}

Com a presente pesquisa, foi possível identificar o SVM como o classificador supervisionado que apresentou melhor desempenho para a área de estudo $(77,272 \%$ de acurácia global e 0,6365 de índice Kappa). Dois outros classificadores também chamaram atenção: Paralelepípedo (none) e SAM (SV), com excelentes resultados em termos de matriz de confusão, mas apresentaram um grande número de pixels não classificados (o Paralelepípedo classificou somente cerca de $25 \%$ dos pixels, e o SAM, somente $60 \%$ ).

A utilização do classificador supervisionado SVM permitiu a classificação das imagens para todos os anos propostos e, com isso, a realização dos mapeamentos de uso e cobertura da terra dos oito municípios da área de estudo. Isso possibilitou a identificação das modificações ocorridas ao longo dos anos, sendo, portanto, uma ferramenta eficaz para a gestão ambiental e territorial por parte do poder público, em virtude do bom desempenho, rapidez e custos reduzidos, uma vez que pode diminuir a necessidade de idas a campo.

A análise multitemporal permitiu identificar o avanço da classe Agropecuária, chegando a quase $70 \%$ de área nos municípios analisados em 2015, ou seja, aumento de mais de 20\% na área, desde 1988. Por outro lado, ocorreu redução da classe correspondente à vegetação nativa (cerrado e cerradão), que passou de 46,29\% em 1988 para 29,24\% em 2015.

O entorno da barragem de Corumbá IV não atende o percentual mínimo de APPs exigido pela legislação ambiental, pois apenas 56,12\% da faixa de 100 metros do entorno é coberto por vegetação nativa. Isso coloca em risco a função ambiental dessa faixa, que é a de preservar os recursos hídricos, a paisagem, a estabilidade geológica e a biodiversidade, facilitar o fluxo gênico de fauna e flora, proteger o solo e assegurar o bem-estar das populações humanas, conforme estabelecido no Código Florestal Brasileiro.

Diante do cenário de aumento do número de reservatórios artificiais para a geração de energia elétrica no país, a metodologia analisada nesta pesquisa demonstrou ser passível de ser usada para que o poder público possa mapear o uso e cobertura da terra no entorno das barragens, assegurando o cumprimento da legislação ambiental em APPs. 


\section{REFERÊNCIAS BIBLIOGRÁFICAS}

Abburu, S., Babu Golla, S., 2015. Satellite image classification methods and techniques: a review. Int. J. Comput. Appl. 119, 20-25. doi:10.5120/21088-3779

Almeida, A.S., Santos, R.L., Chaves, J.M., 2011. Mapeamento de uso e ocupação do solo no município de Jeremoabo-Ba: uso do algoritmo máxima verossimilhança (Maxver), in: XV Simpósio Brasileiro de Sensoriamento Remoto. INPE, Curitiba, p. 7255-7262.

Ana, 2016. Agência Nacional de Águas [WWW Document]. URL http://www.ana.gov.br (acessado 4.2.16).

Anell, 2016. Capacidade de geração do Brasil [WWW Document]. URL http://www2.aneel.gov.br/aplicacoes/capacidadebrasil/capacidadebrasil.cfm

Baltazar, J.E., Os, S., Guerra, D.A., Dutra, L., Camis, N.B., Schwinden, A., Ferraz De Andrade, S., 2015. Future scenarios and trends in energy generation in brazil: supply and demand and mitigation forecasts. J. Clean. Prod. 103, 197-210. doi:10.1016/j.jclepro.2014.09.082

BlackBridge, 2016. Rapideye [WWW Document]. URL http://www.rapideye.com (acessado 4.18.16).

Brasil, 2015a. Balanço energético nacional - BEN 2015. Brasília.

Brasil, 2015b. Cenário econômico 2050. Rio de Janeiro.

Brasil, 2012. Lei $\mathrm{n}^{\mathrm{o}}$ 12.651, de 25 de maio de 2012 [WWW Document]. URL http://www.planalto.gov.br/ccivil_03/_ato2011-2014/2012/lei/112651.htm（acessado 2.28.16).

Brasil, 2002. Resolução Conama Nº 302 De 2002 - Áreas Protegidas - Áreas de Preservação Permanente. Brasília.

Castro, A. dos S., Gomes, R.A.T., Guimarães, R.F., Carvalho Junior, O.A., Martins, É. de S., 2013. Análise da dinâmica da paisagem do município de Formosa do Rio Preto (BA). Espaço Geogr. 16, 307-323.

Chaves, T.A., Carvalho Junior, O.A., Gomes, R.A.T., Guimarães, R.F., 2013. Análise do uso e cobertura da terra e da fragmentação da paisagem no município de Missal-PR. Bol. Geogr. 31, 307-323. doi:10.4025/bolgeogr.v31i2.17796

Chaves, T.A., de Carvalho Júnior, O.A., Gomes, R.A.T., Guimarães, R.F., 2012. Influência do projeto Cultivando Água Boa na presevação da vegetação no município de Itaipulândia 
(PR). Espaço Geogr. 15, 149-172.

Corumbá Concessões, 2014. Visão Geral - Corumbá Concessões S.A. [WWW Document].

Costa, T.C.E.C. Da, Souza, M.G. De, Brites, R.S., 1996. Delimitação e caracterização de áreas de preservação permanente por meio de um sistema de informações geográficas (SIG), in: VIII Simposio Brasileiro de Sensoriamento Remoto. INPE, Salvador, p. 121127.

Crósta, a. P., 1992. Processamento digital de imagens de sensoriamento remoto, Quarta. ed, 1992. Unicamp, Campinas.

Deilmai, B.R., Ahmad, B. Bin, Zabihi, H., 2014. Comparison of two Classification methods (MLC and SVM) to extract land use and land cover in Johor Malaysia. IOP Conf. Ser. Earth Environ. Sci. 20, 012052. doi:10.1088/1755-1315/20/1/012052

Dorais, A., Cardille, J., 2011. Strategies for incorporating high-resolution google earth databases to guide and validate classifications: understanding deforestation in Borneo. Remote Sens. 3, 1157-1176. doi:10.3390/rs3061157

Du, Y., Chang, C.I., Ren, H., Chang, C.C., Jensen, J.O., D’Amico, F.M., 2004. New hyperspectral discrimination measure for spectral characterization. Opt. Eng. 43, 1777. doi:10.1117/1.1766301

Envi, 2004. ENVI User's Guide.

Fearnside, P.M., 2014. Impacts of Brazil's Madeira River Dams: unlearned lessons for hydroelectric development in Amazonia. Environ. Sci. Policy 38, 164-172. doi:10.1016/j.envsci.2013.11.004

Fearnside, P.M., 2013. Credit for climate mitigation by Amazonian dams: loopholes and impacts illustrated by Brazil's Jirau Hydroelectric Project. Carbon Manag. 4, 681-696. doi: $10.4155 / \mathrm{cmt} .13 .57$

Florenzano, T.G., 2011. Iniciação em sensoriamento remoto, Terceira. ed. Oficina de Texto, São Paulo.

Goiás, 2013. Política Florestal do Estado de Goiás (Lei n ${ }^{\circ}$ 18.104/2013) [WWW Document]. URL http://www.gabinetecivil.go.gov.br/leis_ordinarias/2013/lei_18104.htm (acessado 2.28.16).

Grondona, A.E.B., 2009. Avaliação da acurácia dos classificadores de máxima verossimilhança , mínima distância euclidiana e isodata na classificação de imagens da região do Pantanal Centro Estadual de Pesquisas em Sensoriamento Remoto e 
Meteorologia - UFRGS Av . Bento Gonçalves, in: $2^{\circ}$ Simpósio de Geotecnologias no Pantanal. Embrapa / INPE, Corumbá, p. 433-442.

Gualtieri, J. a, Cromp, R.F., 1998. Support vector machines for hyperspectral remote sensing classification, in: Spie 3584. p. 221-232.

Ibama, 2016. Consulta Processo No.: 02001.007059/2001-33 [WWW Document]. URL http://www.ibama.gov.br/licenciamento/index.php

Ibama, 2014. Renovação da Licença de Operação No. 514/2005. Brasília.

Ibama, 2010. Plano ambiental de conservação e uso do entorno do reservatório artifical (PACUERA). Brasilia.

IBGE, 2010. Censo 2010 [WWW Document]. URL http://censo2010.ibge.gov.br/

IMB, 2006. Instituto Mauro Borges [WWW Document]. URL http://www.imb.go.gov.br/ (acessado 3.2.16).

Jensen, J.R., 2009. Sensoriamento remoto do ambiente: uma perspectiva em recursos terrestres, Segunda Ed. ed. Parêntese Editora, São José dos Campos.

Kibler, K.M., Tullos, D.D., 2013. Cumulative biophysical impact of small and large hydropower development in Nu River, China. Water Resour. Res. 49, 3104-3118. doi:10.1002/wrcr.20243

Kruse, F.A., Lefkoff, A.B., Boardman, J.W., Heidebrecht, K.B., Shapiro, A.T., Barloon, P.J., Goetz, A.F.H., 1993. The spectral image processing system (SIPS) - Interactive visualiation and analysis of imaging spectrometer data. Remote Sens. Environ. 44, 145163.

Kuenzer, C., Campbell, I., Roch, M., Leinenkugel, P., Tuan, V.Q., Dech, S., 2013. Understanding the impact of hydropower developments in the context of upstreamdownstream relations in the Mekong river basin. Sustain. Sci. 8, 565-584. doi:10.1007/s11625-012-0195-Z

Lacerda Filho, J.V. de, Rezende, A., Silva, A., 1999. Geologia e recursos minerais do estado de Mato Grosso. Goiânia.

Landis, J.R., Koch, G.G., 1977. The measurement of observer agreement for categorical data. Biometrics 33, 159. doi:10.2307/2529310

Manabe, V.D., Rocha, J.V., 2013. Comparação de classificadores para o mapeamento de culturas agrícolas anuais em Campo Novo do Parecis - MT, utilizando NDVI/MODIS, in: XVI Simposio Brasileiro de Sensoriamento Remoto. INPE, Foz do Iguaçu, p. 0742- 
0747.

Mantovani, J.E., Pereira, A., 1998. Estimativa da integridade da cobertura vegetal de cerrado através de dados TM/Landsat, in: IX Simpósio Brasileiro de Sensoriamento Remoto. INPE, Santos, p. 1455-1466.

Moreira, L., Assad, E.D., 2000. Segmentação e classificação supervisionada para identificar pastagens degradadas, in: GeoInfo 2000. INPE, São Paulo, p. 10-15.

Moreira, M.A., 2011. Fundamentos do sensoriamento remoto e metodologias da aplicação, Quarta. ed. Universidade Federal de Viçosa, Viçosa.

Mountrakis, G., Im, J., Ogole, C., 2011. Support vector machines in remote sensing: A review. ISPRS J. Photogramm. Remote Sens. 66, 247-259. doi:10.1016/j.isprsjprs.2010.11.001

Niknejad, M., Mirzaei Zadeh, V., Heydari, M., 2014. Comparing different classifications of satellite imagery in forest mapping (Case study: Zagros forests in Iran). Int. Res. J. Appl. Basic Sci. 8, 1407-1415.

ONU, 2015. Cultivando Água Boa.

Pal, M., Mather, P.M., 2005. Support vector machines for classification in remote sensing. Int. J. Remote Sens. 26, 1007-1011. doi:10.1080/01431160512331314083

Pinheiro, L.C. da S.J., Gomes, R.A.T., de Carvalho Júnior, O.A., Guimarães, R.F., Oliveira, S.N. De, 2015. Mudanças do uso da terra e fragmentação da paisagem no município de Correntina (BA) durante 1988-2008. RaEga 35, 169-198.

Plourde, L., Congalton, R.G., 2003. Sampling method and sample placement: How do they affect the accuracy of remotely sensed maps? Photogramm. Eng. Remote Sens. 69, 289297. doi:10.14358/pers.69.3.289

Rawat, J.S., Kumar, M., 2015. Monitoring land use/cover change using remote sensing and GIS techniques: A case study of Hawalbagh block, district Almora, Uttarakhand, India. Egypt. J. Remote Sens. Sp. Sci. 18, 77-84. doi:10.1016/j.ejrs.2015.02.002

Redivo, A.L., Farinasso, M., Ramos, V.M., Guimarães, R.F., de Carvalho Júnior, O.A., 2003. Análise multitemporal do rio São Francisco, no trecho entre os municípios de São Romão e São Francisco no estado de Minas Gerais. GeoUerj 1, 1223-1238.

Richards, J., Jia, X., 2006. Remote sensing digital image analysis, Four. ed. Springer, Berlin.

Sader, S.A., Stone, T.A., Joyce, A.T., 1990. Remote sensing of tropical forests: an overview of research and applications using non-photographic sensors. Photogramm. Eng. Remote 
Sens. 56, 1343-1351.

Sano, E.E., Rosa, R., Luís, J., Brito, S., Laerte, E., Ferreira, G., 2008. Notas científicas mapeamento semidetalhado do uso da terra do bioma Cerrado 43, 153-156.

Sarmiento, C.M., Ramirez, G.M., Coltri, P.P., Silva, L.F.L. e, Nassur, O.A.C., Soares, J.F., 2014. Comparação de classificadores supervisionados na discriminação de áreas cafeeiras em Campos Gerais - Minas Gerais. Coffee Sci. 9, 546-557.

Singh, A., 1989. Review Article Digital change detection techniques using remotely-sensed data. Int. J. Remote Sens. 10, 989-1003. doi:10.1080/01431168908903939

Spagnolo, T.F.O., Gomes, R.A.T., de Carvalho Júnior, O.A., Guimarães, R.F., Martins, É. de S., Couto Júnior, A.F., 2012. Dinâmica da expansão agrícola do município de São Desidério (BA) entre os anos de 1984 a 2008, importante produtor nacional de soja, algodão e milho. GeoUerj 23, 603-618.

Srivastava, D.K., Bhambhu, L., Cet, B., 2010. Data classification using support vector machine. Heart.

USGS, 2016. Landsat [WWW Document]. URL http://landsat.usgs.gov/ (acessado 4.15.16).

Vasconcelos, C.H., Novo, E.M.L.D.M., 2004. Mapeamento do uso e cobertura da terra a partir da segmentação e classificação de imagens-fração solo, sombra e vegetação derivadas do modelo linear de mistura aplicado a dados do sensor TM/Landsat5, na região do reservatório de Tucuruí - PA. Acta Amaz. 34, 487-493. doi:10.1590/S004459672004000300014

Yousefi, S., Mirzaee, S., Tazeh, M., Pourghasemi, H., Karimi, H., 2015. Comparison of different algorithms for land use mapping in dry climate using satellite images : a case study of the Central regions of Iran. Desert 20, 1-10.

Yuan, F., Sawaya, K.E., Loeffelholz, B.C., Bauer, M.E., 2005. Land cover classification and change analysis of the Twin Cities (Minnesota) Metropolitan Area by multitemporal Landsat remote sensing. Remote Sens. Environ. 98, 317-328. doi:10.1016/j.rse.2005.08.006 